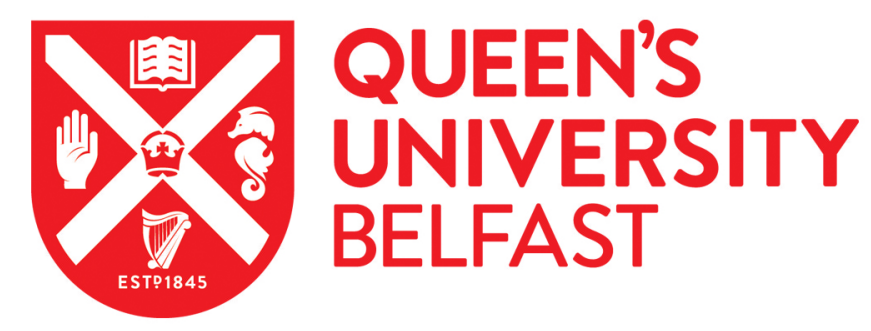

\title{
Luminescent lanthanide (Eu(iii)) cross-linked supramolecular metallo co-polymeric hydrogels: The effect of ligand symmetry
}

Bradberry, S., Dee, G., Kotova, O., McCoy, C. P., \& Gunnlaugsson, T. (2019). Luminescent lanthanide (Eu(iii)) cross-linked supramolecular metallo co-polymeric hydrogels: The effect of ligand symmetry. Chemical Communications, 55(12), 1754-1757. https://doi.org/10.1039/c8cc08888h

Published in:

Chemical Communications

Document Version:

Peer reviewed version

Queen's University Belfast - Research Portal:

Link to publication record in Queen's University Belfast Research Portal

Publisher rights

Copyright 2019 RSC. This work is made available online in accordance with the publisher's policies. Please refer to any applicable terms of use of the publisher.

\section{General rights}

Copyright for the publications made accessible via the Queen's University Belfast Research Portal is retained by the author(s) and / or other copyright owners and it is a condition of accessing these publications that users recognise and abide by the legal requirements associated with these rights.

Take down policy

The Research Portal is Queen's institutional repository that provides access to Queen's research output. Every effort has been made to ensure that content in the Research Portal does not infringe any person's rights, or applicable UK laws. If you discover content in the Research Portal that you believe breaches copyright or violates any law, please contact openaccess@qub.ac.uk. 


\section{Journal Name}

\section{COMMUNICATION}

\section{Luminescent lanthanide (Eu(III)) cross-linked supramolecular metallo co-polymeric hydrogels: The effect of ligand symmetry}

Received 00th January 20xx, Accepted 00th January 20xx

DOI: $10.1039 / \times 0 \times x 00000 x$
Samuel J. Bradberry, ${ }^{* a}$ Garret Dee, ${ }^{a}$ Oxana Kotova, ${ }^{a}$ Colin P. McCoy, ${ }^{b}$ and Thorfinnur Gunnlaugsson* $*^{\mathrm{a}}$ www.rsc.org/

Two lanthanide luminescent naphthyl-dipicolinic amide (dpa) methacrylate monomers for the synthesis of grafted supramolecular co-polymer gels (hydrogels), and their use in the formation of robust covalently cross-linked HEMA hydrogels is presented; the results demonstrate the importance of the ligand symmetry on the Eu(III) emission from the hydrogels.

The application of novel coordination ligands in self-assembled functional structures and materials (e.g. films, gels, MOFs, coordination polymers, etc.) and, generally to form higherorder superstructures has been well developed. ${ }^{1}$ The area of organic polymers is well established and their application and usage is a common part of everyday life. In contrast, supramolecular polymers ${ }^{2}$ are new entry to this area of research, being held together by reversible weak supramolecular interactions. ${ }^{2 a, b}$ The supramolecular approach, normally, relies on the use of low molecular weight gelators $(\mathrm{LMWG})^{3}$, which upon interaction with solvents, soft-materials are formed, which can have the properties and functions of more conventional polymers. ${ }^{4}$ The development of LMWGs possessing metal ion coordination sites has further developed this research field. ${ }^{4,5}$ This enabling cross-linking through metal coordination, ${ }^{5}$ but crosslinking density is fundamental to mechanical properties of polymer and other soft matter. ${ }^{6} \mathrm{~A}$ driving force behind this, has been the design of materials with tuneable functional and structural properties by providing a controllable variation in the cross-linking density and strength. ${ }^{7}$ Additionally, the reversible, or exchangeable, nature of coordination interactions can allow for mechanical properties exhibiting chemical response ${ }^{8}$ or self-healing properties since cross-linking density can be restored after 'damage' has occurred. ${ }^{9}$ Recently, we and others have developed examples of metallo-supramolecular soft materials, from LMWG ligands, ${ }^{10}$ (as well as low molecular mass ionic

\footnotetext{
School of Chemistry and Trinity Biomedical Sciences Institute (TBSI), Trinity College Dublin, The University of Dublin, Dublin 2, Ireland. E-mail: gunnlaut@tcd.ie and bradbers@tcd.ie.

b. School of Pharmacy, Queen's University Belfast, Belfast, BT9 7BL, UK

tElectronic Supplementary Information (ESI) available: General experimental synthetic and additional photophysical details. For ESI and crystallographic details in CIF format See DOI: 10.1039/x0xx00000x
}

a)
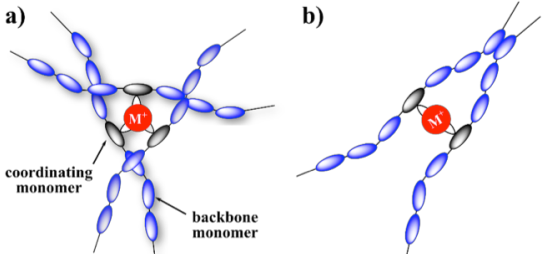

Increasing $\mathbf{M}^{+}$Concentration Triple
Crosslink

Scheme 1 Schematic representation of the nature of crosslinks formed between organic copolymer chains (L) by metal coordination complexes at different metal (M) stoichiometries showing: a) triple crosslinks in $\mathbf{M}_{1}: \mathbf{L}_{3} ;$ b) double crosslinks for $\mathbf{M}_{1}: \mathbf{L}_{2}$; and c) no crosslinking for $\mathbf{M}_{1}: \mathrm{L}_{1}$ stoichiometry.

organo-gelators (LMIOGs)); ${ }^{11}$ where the careful choice of metal ions can be employed to yield luminescent soft materials with tuned emission (and hence, emission colour) properties.

A promising approach to generate both 'hard' and 'soft' materials with rich spectroscopic properties that are robust, and readily processed can be the application of supramolecular principle to macromolecules, i.e. organic polymers, Scheme 1. Novel co-polymers can be designed so that they possess metal binding sites in their polymeric backbone and such structures have been recently reported. ${ }^{12-}$ 13 However, perhaps, the most accessible methodology to achieve macromolecular supramolecular synthons ${ }^{14}$ involves including grafted binding sites that decorate the polymer chains. $^{29}$ This has been achieved by both post-synthetic modification of reactive polymers ${ }^{35}$ or custom design of 'ligand monomer', ${ }^{16}$ that are included directly during polymerisation. With this in mind, and with strong interest in the formation of lanthanide complexes as supramolecular synthons, ${ }^{1 \mathrm{c}, 1 \mathrm{~d}}$ we set out to develop the chiral ligands 1 and $\mathbf{2}$ (Figure 1) based on the use of naphthalene dipicolinic amide (dpa) motive, as monomers that could be co-polymerised into polymer hydrogels to form cross-linked metallo-hydrogels.
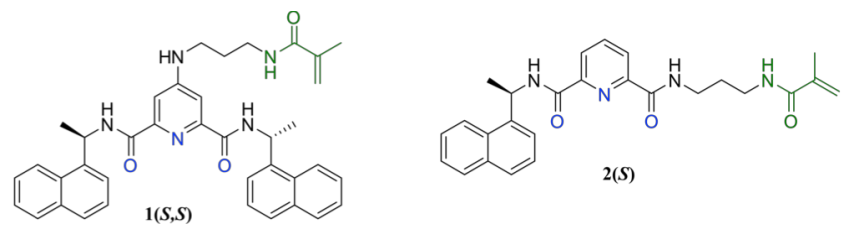

Fig. 1 The monomers, and $\operatorname{Ln}(I I I)$ coordination ligands $\mathbf{1}(S, S)$ and $\mathbf{2}(S)$ used in this study. 
Here the design of $\mathbf{1}$ and $\mathbf{2}$, is based on the assumption that the emission properties can be exclusively assigned to the $\mathbf{M}_{1}: \mathbf{L}_{\mathbf{n}}$ species and report on the crosslinking structure. We anticipated that this stoichiometry would be highly structure depended for $\mathbf{1}$ and $\mathbf{2}$, as the former, being symmetrical and functionalised at the 4-position of the pyridyl unit, would be more accessible to $\mathrm{Eu}(\mathrm{III})$ coordination, favouring the $\mathbf{M}_{\mathbf{1}}: \mathbf{L}_{\mathbf{3}}$ formation, while 2, might be less so, and could give rise to various structural isomers such as $\mathbf{M}_{1}: \mathbf{L}_{3}, \mathbf{M}_{1}: \mathbf{L}_{2}$ and $\mathbf{M}_{1}: \mathbf{L}_{1}$. This would be translated to the Eu(III) emission which is highly coordination dependent (e.g. hydration state or $q$-values). ${ }^{17}$

In principle, both 1 and 2 should be able to form 1:1, 1:2 and 1:3 $\mathbf{M}: \mathbf{L}\left(\mathbf{M}_{\mathbf{1}}: \mathbf{L}_{\mathbf{n}}\right)$ complexes with lanthanide ions, such as $\mathrm{Eu}(\mathrm{III})$, that emits characteristic line-like red emission. As such, these ligands should lead to 'triple crosslinks' where the metal ion connects three separate polymer chains, as depicted in Scheme 1. However, of these three stoichiometries, only the $\mathbf{M}_{1}: \mathbf{L}_{3}$ stoichiometry (where the metal ion is coordinatively saturated and protected from first-sphere $\mathrm{O}-\mathrm{H}$ oscillator quenching), ${ }^{1 \mathrm{c}}$ would be expected to give rise to significant Ln(III)-centred emission. Hence, while both the $\mathbf{M}_{\mathbf{1}}: \mathbf{L}_{\mathbf{2}}$ and $M_{1}: L_{1}$ species would contribute to the crosslinking properties, the Ln(III)-emission arising from such supra-molecular copolymer would be expected to be influenced by quenching from metal-coordinated water molecules ( $q$-value) or from potential geometrical changes within these hydrogels.

Ligands 1 and $\mathbf{2}$ were designed with a pendent methacrylamide moiety that could then be co-polymerised into materials such as $\mathrm{p}(\mathrm{HEMA}-\mathrm{CO}-\mathrm{EGDMA})^{18}$ to yield responsive hydrogels. The synthesis of symmetrical monomer $\mathbf{1}(S, S)$ was achieved by the incorporation of a 1,3-diaminopropyl-chain at the 4-position of the pyridine moiety, starting from chlorosubstituted naphthyl-dpa intermediate $\mathbf{3}(\boldsymbol{S}, \boldsymbol{S})$ (See ESI), followed by treatment of $\mathbf{3}(S, S)$ with methacrylic anhydride, which after workup, gave $\mathbf{1}(S, S)$ as a white solid in $65 \%$ yield. The corresponding asymmetrical ligand monomer $\mathbf{2}(S)$ was synthesised in a seven-step synthesis from dipicolinic acid (Scheme S2 ESI) by generating the mono-benzyl ester which was then coupled to (S)-1-(1-naphthyl)ethylamine, in $85 \%$ yield. Subsequent deprotection, using catalytic hydrogenation, resulted in the formation of the acid $\mathbf{Z}(S)$ in $90 \%$ yield, which was reacted with mono-Boc-protected 1,3-diaminopropane to give 9 in 79\% yield. Deprotection using TFA and treatment with methacrylic anhydride gave the final ligand $2(S)$ in $48 \%$ yield after purification by silica chromatography (See details in ESI).

The formation of complexes with Eu(III) was achieved using microwave-assisted synthesis in $\mathrm{CH}_{3} \mathrm{OH}$ by treating $\mathbf{1}(\boldsymbol{S}, \boldsymbol{S})$ and 2(S) with 0.33 equivalents of $\mathrm{Eu}\left(\mathrm{CF}_{3} \mathrm{SO}_{3}\right)_{3}$ at $70{ }^{\circ} \mathrm{C}$ for 20 minutes, followed by precipitation from $\mathrm{CH}_{3} \mathrm{OH}$ into $\mathrm{Et}_{2} \mathrm{O}$. The formation of both $\left[\mathrm{Eu} .(\mathbf{1}(S, S))_{3}\right]^{3+}$ and $\left[\mathrm{Eu} .(\mathbf{2}(S))_{3}\right]^{3+}$ was demonstrated by HRMS and ${ }^{1} \mathrm{H}$ NMR analysis (see ESI), and by analysing their photophysical properties where the Eu(III) centred emission $\left({ }^{5} D_{0} \rightarrow{ }^{7} F_{J}, J=1-4\right)$ was observed for both complexes upon recording their emission spectra. The ${ }^{1} \mathrm{H} N M R$ in $\mathrm{CD}_{3} \mathrm{OD}$ (See ESI) of $\left[\mathrm{Eu} .(1(S, S))_{3}\right]^{3+}$ and $\left[\mathrm{Eu} .(2(S))_{3}\right]^{3+}$ demonstrated the expected lanthanide-induced shifts in both the naphthyl and the pyridyl resonances due to the
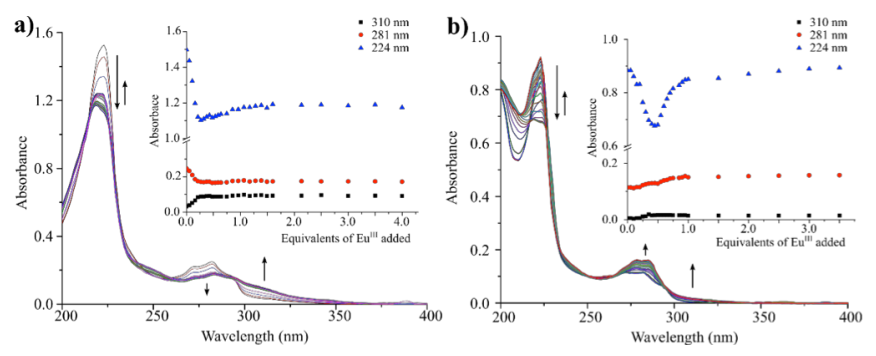

Fig. 2 Overlaid UV-visible absorption spectra from titrations with $0.00 \rightarrow 4.00$ equivalents of $\mathrm{Eu}\left(\mathrm{CF}_{3} \mathrm{SO}_{3}\right)_{3}$ in $\mathrm{CH}_{3} \mathrm{CN}$ for: a) ligand $\mathbf{1}(\mathrm{S}, \mathrm{S})$ inset: single wavelength binding isotherms at $\lambda_{\mathrm{abs}}=310,281$ and $224 \mathrm{~nm}$ as a function of added equivalents of $\mathrm{Eu}(\mathrm{III})$; and b) ligand $2(S)$ inset: single wavelength binding isotherms at $\lambda_{\mathrm{abs}}=310,281$ as a function of added equivalents of Eu(III). Spectra recorded from initial ligand concentrations of $c=1 \times 10^{-5} \mathrm{M}$ at $24^{\circ} \mathrm{C}$.

paramagnetic nature of $\mathrm{Eu}(\mathrm{III})$, consistent with the formations of $\left[\mathrm{Eu} .(\mathbf{1}(S, S))_{3}\right]^{3+}$ and $\left[\mathrm{Eu} .(\mathbf{2}(S))_{3}\right]^{3+}$, which was in agreement with mono-exponential excited state decay, from which the lifetimes and $q$-values were determined (ESI Table S1/S2).

The ligands were next studied in $\mathrm{CH}_{3} \mathrm{CN}$, and upon titration with $\mathrm{Eu}(\mathrm{III})$ to probe their photophysical properties and kinetic self-assembly prior to use within the polymer matrix. The UVvisible absorption spectra of both are shown in Figure 2, where $\mathbf{1}(S, S)$, showed a characteristic absorbance profile and extinction coefficients $\left(\varepsilon=15 \times 10^{4} \mathrm{M}^{-1} \mathrm{~cm}^{-1}\right.$ and $80 \times 10^{3} \mathrm{M}^{-}$ ${ }^{1} \mathrm{~cm}^{-1}$ at $\lambda_{\text {abs }}=224$ and $281 \mathrm{~nm}$, respectively). The fine structure at lower wavelength (assigned to the pyridyl $n \rightarrow \pi^{*}$ and naphthyl $\pi \rightarrow \pi^{*}$ transitions) was present in both ligands from the common chromophores. Ligand $\mathbf{1}(\boldsymbol{S}, \boldsymbol{S})$ was found to be fluorescent, with $\lambda_{\max }$ at $390 \mathrm{~nm}$, upon excitation at the 281 $\mathrm{nm}$ transitions. In contrast, ligand $\mathbf{2}(\boldsymbol{S})$ was not fluorescent, and remained non-emissive throughout the titration.

Upon titration with $\mathrm{Eu}(\mathrm{III})$, which resulted in the formation of the Eu(III) complexes in situ, hyperchromic shifts were observed for both ligands within the 300-350 nm and 200-220 $\mathrm{nm}$ regions. In the region of $279-300 \mathrm{~nm}$, however, the ligands behaved differently; while the formation of the self-assembly between $\mathrm{Eu}(\mathrm{III})$ and $\mathbf{1}(\boldsymbol{S}, \boldsymbol{S})$ resulted in significant hypochromism, the interaction with $\mathbf{2}(S)$ resulted in much smaller changes, as shown in Figure 2. The formation of a selfassembly between $\mathbf{1}(\boldsymbol{S}, \boldsymbol{S})$ and $\mathrm{Eu}(\mathrm{III})$, resulted in an immediate fluorescence quenching, which continued until the addition of 0.30 equivalents of Eu(III) (see ESI for fluorescence analysis). This quenching reflected the formation of the desired $\left[\mathrm{Eu} .(\mathbf{1}(S, S))_{3}\right]^{3+}$ species, and the sensitisation of the $\operatorname{Ln}(\mathrm{III})$ excited state by the antennae. This sensitisation process was
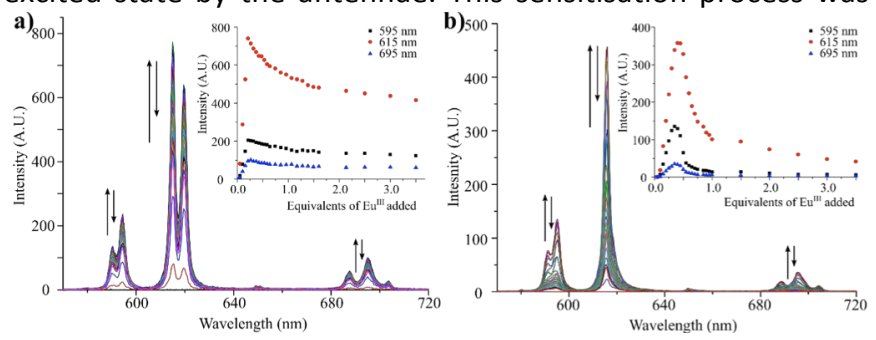

Fig. 3 Overlaid time-gated emission spectra $\left({ }^{5} D_{4} \rightarrow^{7} F_{1}\right)$ from titrations with $0.00 \rightarrow 4.00$ equivalents of $\mathrm{Eu}\left(\mathrm{CF}_{3} \mathrm{SO}_{3}\right)_{3}$ in $\mathrm{CH}_{3} \mathrm{CN}$ for: a) ligand $\mathbf{1}(S, S)$ inset: single wavelength binding isotherms for $\mathrm{Eu}(\mathrm{III})$ emission at $\lambda_{\mathrm{em}}=595,615$ and $695 \mathrm{~nm}$ as a function of added equivalents of $\mathrm{Eu}(\mathrm{III})$; and $\mathbf{b})$ ligand $\mathbf{2}(\boldsymbol{S})$ inset: single wavelength binding isotherms for $\mathrm{Eu}$ (III) emission at $\lambda_{\mathrm{em}}=595,615$ and $695 \mathrm{~nm}$ as a function of added equivalents of $\mathrm{Eu}(\mathrm{III})$. Initial ligand concentrations of $c=1 \times 10^{-5} \mathrm{M}$ at room temperature, $\lambda_{\mathrm{ex}}$ at $281 \mathrm{~nm}$. 

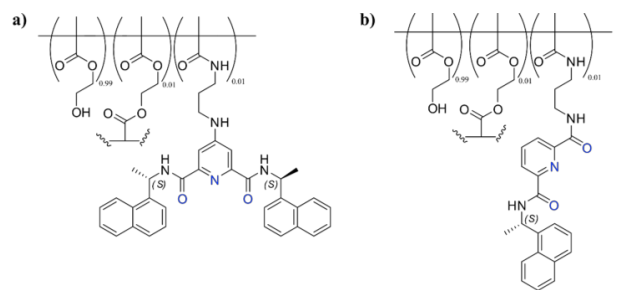

Fig. 4 Schematic representation, showing wt\% ratios, of the structures of the polymers: a) p(HEMA-Co-EGDMA-Co-1(S,S)); and b) p(HEMA-Co-EGDMA-Co-2(S)). Coordinating atoms from crosslinking monomers are shown in blue.

further confirmed by recording the excitation spectra (See ESI, $\left.\lambda_{\mathrm{em}}=615 \mathrm{~nm}\right)$, and the spectra closely matching the corresponding absorbance spectra. As can be seen in Figure 3, beyond the addition of $c a$. 0.35 equivalents of $\mathrm{Eu}(\mathrm{III})$, the Eu(III)-centred emission became rapidly quenched. The quenching upon the addition of one equivalents was $c a .75 \%$ and $25 \%$ for the $\mathbf{2}(S)$ and the $\mathbf{1}(\boldsymbol{S}, \boldsymbol{S})$ titrations respectively. This demonstrates different luminescence intensities for the $\mathbf{M}_{\mathbf{1}}: \mathbf{L}_{\mathbf{2}}$ and $\mathbf{M}_{1}: \mathbf{L}_{\mathbf{1}}$ species, and the importance of being able to tune the photophysical properties of the complexes upon covalent co-polymerisation, as outlined in Figure 1, and Scheme 1. Nonlinear regression analysis of the changes observed in both absorption as well as the Eu(III) centred emissions agreed with a dominant formation of $\mathbf{M}_{1}: \mathbf{L}_{3}$ complexes in the initial stages of the titration before these dissociate into $\mathbf{M}_{\mathbf{1}}: \mathbf{L}_{\mathbf{2}}$ and $\mathbf{M}_{\mathbf{1}}: \mathbf{L}_{\mathbf{1}}$ species. For the changes in the Eu(III) emission, cumulative stability constants $\left(\log \beta_{M 1 L n}, n=1,2,3\right)$ were determined from the modelled data for $\mathbf{1}(S, S)$ as $6.9 \pm 0.1,13.5 \pm 0.2$ and $20.5 \pm$ 0.1 for $\log \beta_{\text {M1L1 }}, \log \beta_{\text {M1L2 }}$ and $\log \beta_{\text {M1L3, }}$, respectively. These constants are in good agreement with structurally related complexes, indicating that the larger 4-positon substituent did not affect the overall stability. ${ }^{19 a}$ For $2(S)$, as $7.6 \pm 0.3,14.5 \pm$ 0.2 and $20.1 \pm 0.4$; being also in agreement with those determined for other asymmetrical naphthyl-dpa systems. ${ }^{19 b}$ The copolymers of $p$ (HEMA-Co-EGDMA-Co-1(S,S)) and $p$ (HEMAco-EGDMA-co-2(S)) were synthesised from a modified procedure previously reported by us. ${ }^{18}$ Schematic structures of the copolymers with $\mathbf{1}(S, S)$ and $\mathbf{2}(S)$ are shown in Figure 4. Solutions of $\mathbf{1}(S, S)$ and $\mathbf{2}(S)$ in HEMA (ca. $0.1 \mathrm{wt} \%$ ) were stirred at RT until the ligand monomers were fully dissolved then treated with EGDMA (1 wt\%) and AIBN (1 wt\%). The mixture of monomers was transferred to a cast and placed into an oven for 6 hours at $90{ }^{\circ} \mathrm{C}$. The bulk materials yielded were hard, brittle and transparent with a thickness of $c a .1 \mathrm{~mm}$. When submerged into $\mathrm{H}_{2} \mathrm{O}$ the materials swelled to become soft and flexible while retaining their transparency (See ESI).

The average equilibration water content (EWC) was found to be $67 \pm 3$ and $75 \pm 4 \%$ for the copolymers of $\mathbf{1}(S, S)$ and $\mathbf{2 ( S )}$, respectively, from mass measurements in the dehydrated and swelled states. These were in agreement with similar p(HEMAco-EGDMA) hydrogels, the slightly lower EWC values were also consistent with the expected greater hydrophobicity of the internal environments of the hydrogels of $\mathbf{1}(S, S)$ and $\mathbf{2}(S)$. The solid materials were characterised for their glass transition temperature $\left(T_{g}\right)$ from DSC measurements (heat flow traces for the second heating cycles for samples of the copolymers with $\mathbf{1}(S, S)$ and $\mathbf{2}(S)$ are shown in ESI). It was suggested that homogenous copolymers had formed with a single $T_{\mathrm{g}}$ observed in each sample at ca. $95^{\circ} \mathrm{C}$ and $104^{\circ} \mathrm{C}$ for p(HEMA-Co-EGDMAco-1(S,S)) and $p($ HEMA-Co-EGDMA-Co-2(S)), respectively. Both $\mathrm{T}_{\mathrm{g}}$ values were higher than that of $\mathrm{p}$ (HEMA-Co-EGDMA) blanks measured experimentally and from literature sources of $c a .86$ ${ }^{\circ} \mathrm{C} .{ }^{24}$ Importantly, it was noted that the $\mathrm{T}_{\mathrm{g}}$ of samples doped with complexes that were non-covalently incorporated into the polymer matrix did not show a shift in $\mathrm{T}_{\mathrm{g}}$ and therefore the change was supportive of successful co-polymerisation. The increase in $T_{\mathrm{g}}$ was consistent with the bulky co-monomers $\mathbf{1}(S, S)$ ad $\mathbf{2}(S)$ reducing the mobility of the HEMA-CO-EGDMA chains acting as 'hooks' to retard the flow of the polymer chains and presenting a larger energy barrier for the phase change. ${ }^{25-27}$ Following this basic structural analysis the photophysical properties of the bulk materials were investigated in both the swelled and dehydrated polymers gel forms. Both the UV-visible absorption and the fluorescence emission spectra were recorded for the materials $p$ (HEMA-coEGDMA-co-1(S,S)) and p(HEMA-co-EGDMA-co-2(S)) (See ESI), and in both the inclusion of the naphthyl-dpa structure was confirmed with no significant shifts in the absorbance of the antennae upon inclusion of the ligands within the polymer. Similarly, both $\mathrm{p}$ (HEMA-co-EGDMA-co-1(S,S)) and p(HEMA-coEGDMA-Co-2(S)) were shown to be fluorescent with a $\lambda_{\max }$ of $390 \mathrm{~nm}$ (See ESI), corresponding to strong blue emission to the 'naked eye' in both the dry polymer and the swelled hydrogels.

Having generated the two gels above, we next induce crosslinking in the gel through supramolecular interactions. ${ }^{13}$ The dry materials were swelled in solutions of $\mathrm{Eu}\left(\mathrm{CF}_{3} \mathrm{SO}_{3}\right)_{3}$, to equilibrate ca. 0.33 equivalents of $\mathrm{Eu}(\mathrm{III})$, and the evolution of Eu(III)-centred emission was observed. In the swelled polymer gels, p(HEMA-co-EGDMA-co-1(S,S)) was strongly emissive, as can be seen in Figure $5 a$ inset. In contrast, p(HEMA-coEGDMA-Co-2(S)) only gave rise to a weak Eu(III)-centred luminescence. While the red emission could be seen to the naked eye, it was clearly, in comparison to p(HEMA-coEGDMA-co-1(S,S)) much less so. The spectral details of the Eu(III)-doped p(HEMA-Co-EGDMA-co-2(S)) hydrogel was also poorer than that seen for p(HEMA-Co-EGDMA-co-1(S,S)), where the emission was well-resolved and the expected twocomponent ${ }^{5} D_{0} \rightarrow{ }^{7} F_{2}$ transition was observed (c.f. Figure $5 a$ ). In fact, the ratios of the emission bands in the Eu(III) spectrum of Eu-doped $\mathrm{p}$ (HEMA-Co-EGDMA-Co-1(S,S)) was in close agreement to those observed for $\left[\mathrm{Eu} .(1(S, S))_{3}\right]^{3+}$ solution. This suggested that the tethering of the complex to the polymer matrix did not significantly distort the Eu(III) coordination geometry by moving from the 'free' solution state to the more restricted tethered complexes in the supramolecular copolymer gel. Luminescence lifetime measurements were recorded of the $\mathrm{Eu}(\mathrm{III})$-crosslinked hydrogels before and after being dehydrated (See ESI Table S3). The decay profiles were best fitted to mono-exponential decay for both systems in their hydrated state (see ESI), which gave lifetimes of $1.32 \pm$ 0.01 and $2.79 \pm 0.01$ in $\mathrm{H}_{2} \mathrm{O}$ and $\mathrm{D}_{2} \mathrm{O}$, respectively, for $\mathrm{p}$ (HEMAco-EGDMA-co-1(S,S)), while these values for p(HEMA-coEGDMA-Co-2(S)) were $0.48 \pm 0.03$ and $2.65 \pm 0.02$. From these values, $q$, of the complexes was determined as $q=0$ and 3 , respectively. In Eu(III)-doped materials p(HEMA-co-EGDMA-co- 

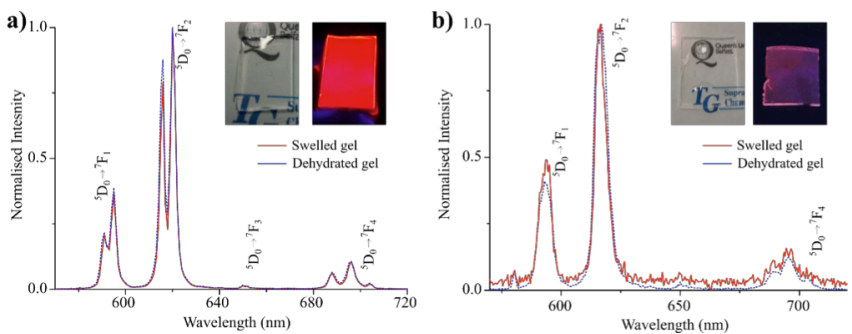

Figure 5. Normalised time-gated emission spectra $\left({ }^{5} D_{4} \rightarrow{ }^{7} F_{J}\right)$ from: a) $p(H E M A-c O-$ EGDMA-co-1(S,S)) swelled in 0.33 equv. of $\mathrm{Eu}(\mathrm{III})$ (red) and the corresponding dehydrated gel (blue), inset: photographs of materials swelled in 0.33 equv. of $\mathrm{Eu}(\mathrm{III})$ under ambient and UV light; and b) p(HEMA-co-EGDMA-co-2(S)) swelled in 0.33 equivalents of $\mathrm{Eu}(\mathrm{III})$ (red) and the dehydrated gel (blue), inset: photographs of materials swelled in 0.33 equv. of Eu(III) under ambient and UV light. Spectra were recorded of the swelled gels in a supernatant of $\mathrm{H}_{2} \mathrm{O}$ at $24^{\circ} \mathrm{C}$.

$\mathbf{1}(S, S)$ ), once dehydrated, showed bi-exponential lifetimes, confirming a proof-of-principle that internal stresses and changes in local conditions within the materials could be reported by Eu(III)-centred emission. Moreover, it was clearly demonstrated that symmetrical monomer $\mathbf{1}(\boldsymbol{S}, \boldsymbol{S})$, has advantages over $\mathbf{2}(\boldsymbol{S})$; the results strongly suggest that the formation of the $M_{1}: L_{3}$ stoichiometry is less favoured for $\mathbf{2}(S)$, as $q=3$. This is an indication that the $\mathbf{M}_{1}: \mathbf{L}_{2}$ stoichiometry is the dominate species in the $\mathbf{2}(\boldsymbol{S})$ polymer (e.g. coordinative saturation being more challenging for $\mathbf{2}(S)$ vs. $\mathbf{1}(S, S)$ polymer). This result in less emissive materials, the two systems forming 'triple crosslinks' and 'double crosslinks', respectively.

Overall, the additional hydrophobic exclusion of competing $\mathrm{H}_{2} \mathrm{O}$ in the symmetrical system results in more robust coordination. Indeed, this is consistent with our observations of photophysical enhancement of naphthyl-dpa systems in aqueous media. ${ }^{20}$ This shows the importance of symmetry in such monomer ligand design. We are currently evaluating the application of these system further. We thank the Science Foundation Ireland (SFI PI Award 13/IA/1865) for financial support, and Drs N. Irwin and J. Hardy (QUB), and Drs J. E. O'Brien, M. Reuther and G. Hessman (TCD) for their help.

\section{Notes and references}

1. a) R. G. Weiss and P. Terech, Molecular Gels: Materials with Self-Assembled Fibrillar Networks, Springer Netherlands, 2006; b) B. Escuder and J. F. Miravet, Functional Molecular Gels, RCS, 2013. c) D. E. Barry, D. F. Caffrey and T. Gunnlaugsson, Chem. Soc. Rev, 2016, 45, 3244-3274. d) S. J. Bradberry, A. J. Savyasachi, M. Martinez-Calvo and T. Gunnlaugsson, Coord. Chem. Rev. 2014, 273-274, 226-241.

2. a) T. F. A. De Greef, M. M. J. Smulders, M. Wolffs, A. P. H. J. Schenning, R. P. Sijbesma, and E. W. Meijer, Chem. Rev., 2009, 109, 5687-5754; b) A. J. Savyasachi, O. Kotova, S. Shanmugaraju, S. J. Bradberry, G. M. Ó Máille, T. Gunnlaugsson, Chem, 2017, 3, 764-811; c) Gunnlaugsson, T. Nature Chem., 2016, 8, 6-7.

3. a) R. Dobrawa and F. Würthner, J. Polym. Sci. A Polym. Chem., 2005, 43, 4981-4995; b) L. E. Buerklea and S. J. Rowan, Chem. Soc. Rev., 2012, 41, 6089-6102; c) A. Dawn, B. Roy and S. Shinkai, in Chemoresponsive Materials: Stimulation by Chemical and Biological Signals, RSC, 2015, pp. 67-97; d) T. Aida, E. W. Meijer and S. I. Stupp, Science, 2012, 335, 813.

4. a) K. M. Herbert, S. Schrettl, S. J. Rowan and C. Weder, Macromol. 2017, 50, 8845-8870; b) J. M. Stanley and B. J. Holliday, Coord. Chem. Rev., 2012, 256, 1520-1530. c)
Piepenbrock, M.-O. M.; Lloyd, G. O.; Clarke, N.; Steed, J. W., Chem. Rev., 2010, 10, 1960-2004; d) A. Y.-Y. Tam and V. W.-W. Yam, Chem. Soc. Rev., 2013, 42, 1540-1567.

5. a) J. I. Lovitt, C. S. Hawes, A. D. Lynes, B. Haffner, M. E. Möbius and T. Gunnlaugsson, Inorg. Chem. Front., 2017, 4, 296-308, b) A. Winter and U. S. Schubert, Chem. Soc. Rev., 2016, 45, 53115357; c) J. Zhang and C.-Y. Su, Coord. Chem. Rev., 2013, 257, 1373-1408.

6. a) D. L. Safranski and K. Gall, Polymer, 2008, 49, 4446-4455.; b) A. J. Varma, S. V. Deshpande and J. F. Kennedy, Carbohydr. Polym., 2004, 55, 77-93. C) Z. Wei, J. H. Yang, J. Zhou, F. Xu, M. Zrinyi, P. H. Dussault, Y. Osada and Y. M. Chen, Chem. Soc. Rev., 2014, 43, 8114-8131.

7. G. R. Whittell, M. D. Hager, U. S. Schubert and I. Manners, Nature Materials, 2011, 10, 176-188.

8. W. Weng, J. B. Beck, A. M. Jamieson and S. J. Rowan, J. Am. Chem. Soc., 2006, 128, 11663-11672.

9. B. W. Greenland, G. L. Fiore, S. J. Rowan and C. Weder, RSC Polym. Chem. Ser., 2013, 5, 92-125.

10. a) O. Kotova, R. Daly, C. M.G. dos Santos, P. E. Kruger, J. J. Boland and T. Gunnlaugsson, Inorg. Chem. 2015, 54, 7735-7741; b) M. Martínez-Calvo, O. Kotova, M. E. Möbius, A. P. Bell, T. McCabe, J. J. Boland and T. Gunnlaugsson, J. Am. Chem. Soc., 2015, 137, 1983-1992; c) E. P. McCarney, J. P. Byrne, B. Twamley, M. Martinez-Calvo, G. Ryan, M. E. Mobius and T. Gunnlaugsson, Chem. Commun., 2015, 51, 14123-14126.

11. J. R. Engstrom, A. J. Savyasachi, M. Parhizkar, A. Sutti, C. S. Hawes, J. M. White, T Gunnlaugsson and F. M. Pfeffer, Chem. Sci., 2018, 9, 5233-5241.

12. L. Munuera and R. K. O'Reilly, Dalton Trans., 2010, 39, 388-391; b) L. Babel, T. N. Y. Hoang, H. Nozary, J. Salamanca, L. Guenee and C. Piguet, Inorg. Chem., 2014, 53, 3568-3578; c) X.-Y. Chen, X. Yang and B. J. Holliday, J. Am. Chem. Soc., 2008, 130, 15461547. d) K. Binnemans, Chem. Rev., 2009, 109, 4283- 4374.

13. a) M. Rehahn, Acta Polym., 1998, 49, 201-224; b) M. O. Wolf, Adv. Mater., 2001, 13, 545-553.

14. G. R. Desiraju, Angew. Chem. Int. Ed. Engl., 1995, 34, 2311-2327. 15. a) B. Chen, G. Wen, J. Wu and J. Feng, Macromol. Rapid Commun., 2015, 36, 1836-1840. b) K. Ghosh, E. R. M. Balog, J. L. Kahn, D. P. Shepherd, J. S. Martinez and R. C. Rocha, Macromol. Chem. Phys., 2015, 216, 1856-1861.

16. a) C. Yang, J. Xu, R. Zhang, Y. Zhang, Z. Li, Y. Li, L. Liang and M. Lu, Sens. Actuators, B, 2013, 177, 437-444; b) B. Li, Z.-J. Ding, Z. Li and H. Li, J. Mater. Chem. C, 2018, 6, 6869-6874.

17. a) J. Lehr, P. D. Beer, S. Faulkner and J. J. Davis, Chem. Commun. 2014, 50, 5678-5687; b) J. A. Kitchen, D. E. Barry, L. Mercs, M. Albrecht, R. D. Peacock and T.Gunnlaugsson, Angew. Chem. Int. Ed., 2012, 51, 704-708.

18. E. M. Surender, S. J. Bradberry, S. A. Bright, C. P. McCoy, D. C. Williams and T. Gunnlaugsson, J. Am. Chem. Soc., 2017, 139, 381-388

19. a) O. Kotova, J. A. Kitchen, C. Lincheneau, R. D. Peacock and T. Gunnlaugsson, Chem. - Eur. J., 2013, 19, 16181-16186; b) 0. Kotova, B. Twamley, J. O'Brien, R. D. Peacock, S. Blasco, J. A. Kitchen, M. Martínez-Calvo and T. Gunnlaugsson, Chem. Sci., 2015, 6, 457-471.

20. S. J. Bradberry, A. J. Savyasachi, R. D. Peacock and T. Gunnlaugsson, Faraday Discuss., 2015, 185, 413-431. 


\section{Luminescent lanthanide (Eu(III)) cross-linked supramolecular metallo co- polymeric hydrogels: The effect of ligand symmetry}

Samuel J. Bradberry, ${ }^{* a}$ Garret Dee, ${ }^{\text {a }}$ Oxana Kotova, ${ }^{a}$ Colin P. McCoy, ${ }^{b}$ and Thorfinnur Gunnlaugsson*a

a School of Chemistry and Trinity Biomedical Sciences Institute (TBSI), Trinity College

Dublin, The University of Dublin, Dublin 2, Ireland.

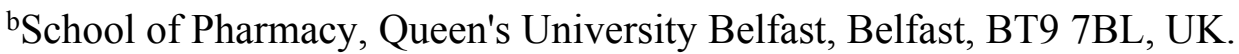

*Emails: gunnlaut@tcd.ie and bradbers@tcd.ie. 


\section{General methods and materials}

All reagents and solvents were purchased from commercial suppliers and used without further purification. Dry solvents were prepared following standard procedures ${ }^{1}$ or by solidphase solvent purification. Synthesis was completed, unless stated, under inert atmospheres of $\mathrm{N}_{2}$ or Ar. Flash chromatography was carried out using a TeledyneIsco CombifFlash Rf 200 automated purification system; pre-packed normal phase, amine or C-18 silica cartridges were used supplied by TeledyneIsco RediSep ${ }^{\circledR}$ or Grace Technologies. Thin-layer chromatography (TLC) was conducted using MerckMillipore Kiesegel $60 \mathrm{~F}_{254}$ silica or alumina plates and visualised under $\lambda=254 \mathrm{~nm}$; amine containing compounds were visualised using Ninhydrin in EtOH. Melting points were determined using an Electrothermal IA900 digital apparatus. Infrared spectra were recorded (in $\mathrm{cm}^{-1}$ ) using a PerkinElmer Spectrum One FT-IR Spectrometer fitted with a universal ATR sampling accessory from solid samples under $70 \mathrm{~N}$ compression. Elemental analysis for \% carbon, hydrogen and nirogen was carried out at the Microanalytical Laboratory, School of Chemistry and Chemical Biology, University College Dublin. Microwave-assisted reactions were carried out in a Biotage Initiator Eight EXP microwave reactor using 2-5 mL or 10-20 mL sealed vials.

\section{NMR Spectroscopy}

NMR spectra were recorded using a Bruker DPX-400 Avance spectrometer or Agilent DD2/LH spectrometer at frequencies of $400.13 \mathrm{MHz}$ and $100.6 \mathrm{MHz}$ for ${ }^{1} \mathrm{H}-\mathrm{NMR}$ and ${ }^{13} \mathrm{C}$ NMR, respectively; or a Bruker AV-600 spectrometer at frequencies of $600.1 \mathrm{MHz}$ and 150.2 $\mathrm{MHz}$ for ${ }^{1} \mathrm{H}-\mathrm{NMR}$ and ${ }^{13} \mathrm{C}-\mathrm{NMR}$, respectively. All spectra were recorded in commercially sourced per-deuterated solvents and referenced to residual proton signals of those solvents. Recorded free-induction decay signals were Fourier-transformed and processed using MestreNova v.6 without apodization and chemical shifts expressed in parts per million (ppm / $\delta)$ and coupling constants $(J)$ in $\mathrm{Hz}$.

\section{Mass Spectrometry}

Mass spectrometry was completed in the departmental mass spectrometery service of the School of Chemistry, Trinity College Dublin. Electrospray mass spectrometry was completed using a Mass Lynz NT V 3.4 on a Waters 600 controller with 996 photodiode array detector. HPLC grade solvents were used throughout and accurate molecular weights determined via a peak-matching method against enkephaline standard reference $(m / z=556.2771)$; all accurate masses were reported within \pm 5 ppm of the calculated mass. MALDI Q-ToF mass spectra were recorded on a MALDI Q-TOF Premier (Waters Corporation, Micromass MS 
Technologies, Manchester, UK) and high-resolution mass spectrometer was performed using Glu-Fib as an internal reference $(m / z=1570.677)$.

Photophysical measurements

All photophysical measurements were taken in spectroscopic grade solvents (SigmaAldrich $\left.{ }^{\circledR}\right)$ and were used in quartz cells purchased from HellmaAnalytics with path length $10 \mathrm{~mm}$. Spectroscopic solutions were prepared from stock solutions using Pipetman ${ }^{\circledR}$ Classic micropipettes (Gilson, Inc).

UV-visible absorption and luminescence spectroscopy

UV-visible absorption spectra were recorded using a Varian Cary 50 spectrophotometer, a spectroscopic window of $450-200 \mathrm{~nm}$ was used for all spectra with applied baseline correction from blank solvent. Luminescence spectra (fluorescence and time-gated emission) were recorded using a Varian Cary Eclipse spectrophotometer and reported in arbitrary units; spectral windows of $570-720 \mathrm{~nm}$ was applied for $\mathrm{Eu}(\mathrm{III})$ emission. Time-gated emission spectra were recorded over an average integration time for 0.1 seconds. The temperature was kept constant throughout the measurements at $298 \mathrm{~K}$ by using a thermostated unit block.

\section{Luminescence lifetime measurements}

Luminescence lifetime measurements of $\mathrm{Eu}(\mathrm{III})$-centred emission was recorded using a Varian Cary Eclipse spectrophotometer as a time-resolved measurement at $298 \mathrm{~K}$. Excitation was made at the maximum absorbance (ca. $281-310 \mathrm{~nm}$ ) and, following a gate time, the decay in intensity of the ${ }^{5} \mathrm{D}_{0} \rightarrow{ }^{7} \mathrm{~F}_{2}$ transition of $\mathrm{Eu}(\mathrm{III})$ was monitored. Final lifetimes were averaged from at least five measurements at different gate times between $0.02-0.04 \mathrm{~ms}$. The recorded decay curves were fitted to mono- or bi-exponential decay functions using Origin ${ }^{\circledR}$ 8.5 .

Differential scanning calorimetry

Differential scanning calorimetry (DSC) was carried out either in at the School of Pharmacy, Queen's University Belfast using a DSC 2920 Modulated DSC (TA Instruments) or in the School of Chemistry, Trinity College Dublin using a DSC 8000 (Perkin Elmer). Samples were prepared in DSC pans provided by TA Instruments and PerkinElmer, respectively, and heat flows measured against a reference pan. Both instruments were fitted with recirculating coolers and programs run with heating and cooling rates of $5{ }^{\circ} \mathrm{C} / \mathrm{min}$ and $10^{\circ} \mathrm{C} / \mathrm{min}$, respectively. The temperature extremes were held isothermally between each heating and 
cooling run. $T_{g}$ values were estimated at the centre point by tangent extrapolation methods using TA Universal Analysis or Pyris ${ }^{\circledR}$ software associated with the respective instruments. 
<smiles>C[C@H](NC(=O)c1cc(Cl)cc(C(=O)N[C@H](C)c2cccc3ccccc23)n1)c1cccc2ccccc12</smiles>

Chelidamic acid monohydrate was heated $(0.40 \mathrm{~g}, 1.99$ $\mathrm{mmol})$ in $\mathrm{SOCl}_{2}(5 \mathrm{~mL})$ with cat. DMF (3 drops) at 50 ${ }^{\circ} \mathrm{C}$ for 18 hours until complete dissolution. Excess $\mathrm{SOCl}_{2}$ was distilled under reduced pressure. The residue dried under high vacuum then dissolved into THF (50 $\mathrm{mL})$ and treated with $(S)-1-(1-$ naphthyl)ethylamine $(0.64 \mathrm{~mL}, 3.99 \mathrm{mmol})$ and TEA $(0.56$ $\mathrm{mL}, 3.99 \mathrm{mmol}$ ) at $0{ }^{\circ} \mathrm{C}$. After 30 minutes the reaction was allowed to warm to RT and stirred for 48 hours. Solvent was removed in vacuo then residues redissolved into $\mathrm{CH}_{2} \mathrm{Cl}_{2}(150 \mathrm{~mL})$. This solution was washed with sat. aq. $\mathrm{NaHCO}_{3}(2 \times 50 \mathrm{~mL})$, brine $(50 \mathrm{~mL})$ and the organic phase dried over $\mathrm{MgSO}_{4}$, filtered and concentrated in vacuo. Trituration under $\mathrm{MeOH}$ and filtration of resultant solids yielded $\mathbf{1}(S, S)$ as a white solid $(0.615 \mathrm{~g}, 1.21 \mathrm{mmol}, 61 \%)$; m.p. $129.9-131.2{ }^{\circ} \mathrm{C}$; HRMS $(\mathrm{m} / z)\left(\mathrm{ES}^{+}\right)$Calculated for $\mathrm{C}_{31} \mathrm{H}_{27} \mathrm{ClN}_{3} \mathrm{O}_{2} \mathrm{~m} / z=508.1766[\mathrm{M}+$ $\mathrm{H}]^{+}$. Found $m / \mathrm{z}=507.1714 ;{ }^{1} \mathrm{H}$ NMR $\left(400 \mathrm{MHz}, \mathrm{CDCl}_{3}\right) \delta: 8.34(2 \mathrm{H}, \mathrm{s}$, pyridyl-CH$), 8.13$ $(2 \mathrm{H}$, br. d, $J=5.9 \mathrm{~Hz}$, naph-CH), $7.85(2 \mathrm{H}$, br. d, $J=7.5 \mathrm{~Hz}$, naph-CH), $7.63(2 \mathrm{H}, \mathrm{d}, J=7.7$ $\mathrm{Hz}$, naph-CH), 7.55 - 7.49 (4H, m, naph-CH), 7.49 - 7.39 (4H, m, naph-CH), 6.12 - 5.89 $(2 \mathrm{H}, \mathrm{m}, \mathrm{pyr}-\mathrm{CH}), 1.67\left(6 \mathrm{H}, \mathrm{d}, J=6.6 \mathrm{~Hz}, \mathrm{CH}_{3}\right) .{ }^{13} \mathrm{C}$ NMR $\left(100 \mathrm{MHz}, \mathrm{CDCl}_{3}\right) \delta: 161.3$, $150.0,147.7,137.8,133.9,130.9,128.9,128.6,126.7,126.0,125.5,125.2,123.1,122.7$, 45.4, 20.8 ; IR $v_{\max }\left(\mathrm{cm}^{-1}\right): 3281,2976,1644,1599,1510,1373,1334,1232,1173,1118$, $1081,998,900,860,800,777,765,681$.

4-(3-Aminopropylamino)-N,N'-bis((S)-1-(naphthalen-1-yl)ethyl)pyridine-2,6-dicarboxamide $4(S, S)$

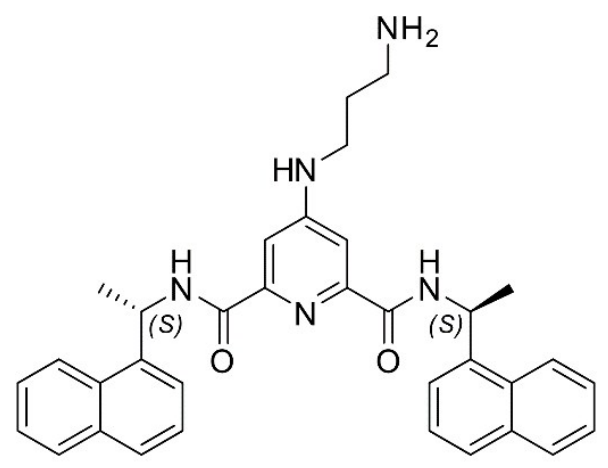

Compound $\mathbf{3}(\boldsymbol{S}, \boldsymbol{S})$ was suspended in $1,3-$ diaminopropane as solvent and refluxed for 18 hours. Upon completion by TLC reaction mixtures were poured into iced-water $(3 \mathrm{~mL})$ precipitating beige solids which were isolated by filtration and washed with excess $\mathrm{H}_{2} \mathrm{O}$ and dried in vacuo. Crude mixtures were eluted on silica (RediSep ${ }^{\circledR}$ 40g, 10 CV DCM followed by gradient elution $0 \rightarrow 15 \% \mathrm{CH}_{3} \mathrm{OH}$ in $\mathrm{DCM}$ ), product containing fractions were concentrated to give pure products as a white solid. Yield: $45 \%$; m.p. $172-174{ }^{\circ} \mathrm{C}$; HRMS $(m / z)\left(\mathrm{ES}^{-}\right)$Calculated for $\mathrm{C}_{34} \mathrm{H}_{34} \mathrm{~N}_{5} \mathrm{O}_{2} \quad m / z=544.2713$. Found $m / z=544.3138$. $[\mathrm{M}+\mathrm{H}]^{+} .{ }^{1} \mathrm{H}$ NMR (600 MHz, $\mathrm{CDCl}_{3}$, broad signals possible aggregation) $\delta 8.10(\mathrm{~m}, 3 \mathrm{H}$, aryl-CH), 7.79 
(m, 4H, aryl-CH), $7.42(\mathrm{~m}, 8 \mathrm{H}$, aryl-CH), 5.96 (app. s, 1H, aliphatic- $\mathrm{CH}), 3.15\left(\mathrm{~m}, 4 \mathrm{H}, \mathrm{CH}_{2}\right)$, 2.07 (m, 2H, $\mathrm{CH}_{2}$ ), 1.55 (app. s, 6H, $\mathrm{CH}_{3}$ ). ${ }^{13} \mathrm{C} \mathrm{NMR} \mathrm{(151} \mathrm{MHz,} \mathrm{CDCl}_{3}$ ) $\delta$ 163.70, 155.70, $149.10,138.72,133.89,130.81,128.88,128.11,127.28,126.45,125.98,125.78,125.63$, $125.44,125.24,123.23,122.89,122.61,121.40,46.51,45.30,30.92,29.70,24.74,21.24$. IR $v_{\max }\left(\mathrm{cm}^{-1}\right): 3285,3048,2934,1654,1605,517,1309,1467,1241$ 1144, 1116, 873, 9899, 777.

4-(3-Methacrylamido-propylamino)-N,N'-bis((S)-1-(naphthalen-1-yl)ethyl)pyridine-2,6dicarboxamide - $1(S, S)$

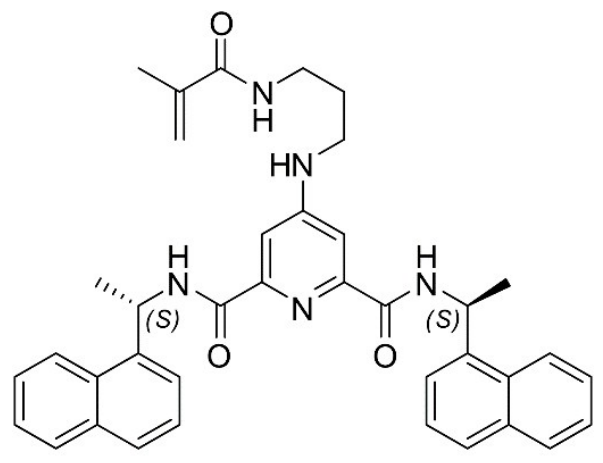

To a solution of $4(S, S)(0.250 \mathrm{~g}, \mathrm{xx} \mathrm{mmol}, 1$ equiv. $)$ in $\mathrm{CH}_{2} \mathrm{Cl}_{2}(20 \mathrm{~mL})$ at $0{ }^{\circ} \mathrm{C}$ methacrylic anhydride $(0.2 \mathrm{~mL}$, 1.26 mmol, 3.4 equiv.) was added and the reaction stirred at RT for 24 hours. The reaction mixture was subsequently diluted with $\mathrm{CH}_{2} \mathrm{Cl}_{2}(50 \mathrm{~mL})$ and washed with $\mathrm{H}_{2} \mathrm{O}(100 \mathrm{~mL})$ and $\mathrm{NaCl}$ (sat. aq., $\left.100 \mathrm{~mL}\right)$. The organic phase was dried over $\mathrm{MgSO}_{4}$, filtered and concentrated in vacuo to afford a crude oily liquid which was eluted in silica (RediSep ${ }^{\circledR}, 5 \%$ $\mathrm{CH}_{3} \mathrm{OH}$ in $\mathrm{CH}_{2} \mathrm{Cl}_{2}$ ). Product containing fractions were combined and concentrated in vacuo to give $\mathbf{1 2 7}(S, S)$ as a white solid. Yield: $65 \%$; HRMS $(\mathrm{m} / z)\left(\mathrm{ES}^{+}\right)$Calculated for $\mathrm{C}_{38} \mathrm{H}_{38} \mathrm{~N}_{5} \mathrm{O}_{3}$ $m / z=612.2975[\mathrm{M}-\mathrm{H}]^{-}$. Found $m / z=612.2964 .{ }^{1} \mathrm{H}$ NMR $\left(400 \mathrm{MHz}, \mathrm{CDCl}_{3}\right) \delta 8.11(\mathrm{~d}, J=$ $4.5 \mathrm{~Hz}, 2 \mathrm{H}$, aryl-CH), 7.85 (dd, $J=22.1,17.2 \mathrm{~Hz}, 6 \mathrm{H}$, aryl-CH), $7.58-7.33$ (m, 8H, aryl$\mathrm{CH}), 6.04-5.78(\mathrm{~m}, 2 \mathrm{H}$, aliphatic- $\mathrm{CH}), 5.66(\mathrm{~s}, 1 \mathrm{H}$, alkene- $\mathrm{CH}), 5.30(\mathrm{~s}, 1 \mathrm{H}$, alkene- $\mathrm{CH})$, $3.25\left(\mathrm{~m}, 4 \mathrm{H}, \mathrm{CH}_{2}\right), 1.72\left(\mathrm{~m}, 2 \mathrm{H}, \mathrm{CH}_{2}\right) 1.61\left(\mathrm{~m}, 6 \mathrm{H}, \mathrm{CH}_{3}\right), 1.24\left(\mathrm{~s}, 3 \mathrm{H}, \mathrm{CH}_{3}\right) .{ }^{13} \mathrm{C} \mathrm{NMR}(151$ $\left.\mathrm{MHz}, \mathrm{CDCl}_{3}\right) \delta 167.03,156.55,144.09,135.33,133.98,133.38,130.95,128.91,128.34$, $127.28,126.55,125.84,125.38,123.30,77.22,77.01,76.80,45.52,29.70,21.05,18.69$, 18.58, 14.77. IR $v_{\max }\left(\mathrm{cm}^{-1}\right): 3290,3051,2961,2935,2870,1763,1651,1607,1519,1451$, 1376, 1172, 990, 868, 800, 776.

6-((benzyloxy)carbonyl)pyridine-2-carboxylic acid - $6^{\text {a }}$<smiles>O=C(O)c1cccc(C(=O)OCc2ccccc2)n1</smiles>

2,6-pyridinedicarboxylic acid (5, $2.043 \mathrm{~g}, 12.23 \mathrm{mmol}, 1$ equiv.) and $\mathrm{NaHCO}_{3}$ (1.233 g, $14.66 \mathrm{mmol}, 1.2$ equiv.) were stirred in anhydrous $N, N$-dimethylformamide (DMF) $(100 \mathrm{~mL})$ at $60{ }^{\circ} \mathrm{C}$ under argon for 30 minutes. Benzyl bromide (1.7 mL, $15 \mathrm{mmol}, 1.2$ equiv.) was added dropwise and the reaction stirred under argon at $60{ }^{\circ} \mathrm{C}$ for 24 hours. The resulting yellow solution was diluted with water $(100 \mathrm{ml})$, basified to $\mathrm{pH} 8$ with $\mathrm{NaHCO}_{3}$ (sat. aq.) and 
extracted with EtOAc $(2 \times 100 \mathrm{ml})$. The aqueous layer was then acidified to $\mathrm{pH} 3$ with conc. $\mathrm{HCl}$ and extracted with EtOAc $(2 \times 100 \mathrm{ml})$. The organic layer was dried over $\mathrm{MgSO}_{4}$, filtered and the solvent removed in vacuo. The resulting solid was dissolved in $\mathrm{CH}_{2} \mathrm{Cl}_{2}(100$ $\mathrm{ml})$. This solution was washed with water $(100 \mathrm{ml})$ and $\mathrm{NaCl}$ (sat. aq., 3 x $100 \mathrm{~mL})$ after which the organic layer was dried over $\mathrm{MgSO}_{4}$, filtered and dried in vacuo to afford $\mathbf{6}$ as a white solid. Yield: 1.0205 g, 33 \%; m.p. 133 - $134{ }^{\circ} \mathrm{C}$; HRMS (m/z) (ES-) Calculated for $\left[\mathrm{C}_{14} \mathrm{H}_{10} \mathrm{NO}_{4}\right]^{-} m / z=256.0610[\mathrm{M}-\mathrm{H}]^{-}$. Found $m / \mathrm{z}=256.0615 ;{ }^{1} \mathrm{H} \mathrm{NMR}\left(400 \mathrm{MHz}, \mathrm{CDCl}_{3}\right)$ $\delta 8.46-8.34(\mathrm{~m}, 2 \mathrm{H}$, pyridine-CH), $8.12(\mathrm{t}, J=7.8 \mathrm{~Hz}, 1 \mathrm{H}$, pyridine- $\mathrm{CH}), 7.53-7.34(\mathrm{~m}, 5 \mathrm{H}$, phenyl-CH), $5.46\left(\mathrm{~s}, 2 \mathrm{H}, \mathrm{CH}_{2}\right) ;{ }^{13} \mathrm{C} \mathrm{NMR}\left(101 \mathrm{MHz}, \mathrm{CDCl}_{3}\right) \delta 163.5,146.7,146.4,139.7$, 135.0, 128.9, 128.8, 128.6, 126.8, 68.1. IR $v_{\max }\left(\mathrm{cm}^{-1}\right): 2575,1736,1692,1576,1499,1466$, 1418, 1376, 1289, 1243, 1151, 1083, 994, 956, 941, 856, 797, 754, 729, 710, 691.

(R)-6-((1-(naphthalen-1-yl)ethyl)carbamoyl)-2-((benzyloxy)carbonyl)-pyridine -6a(S) a

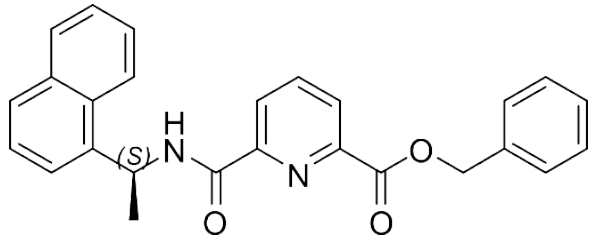

Compound 6 (1.021 g, $3.97 \mathrm{mmol}, 1$ equiv.), (R)-1-(1naphthyl)-ethylamine (0.64 mL, $3.97 \mathrm{mmol}, 1$ equiv.), HOBt (0.536 g,3.97 mmol, 1 equiv.) and triethylamine (0.55 mL, 3.97 mmol, 1 equiv.) were stirred in anhydrous THF at $0{ }^{\circ} \mathrm{C}(50 \mathrm{ml})$ under argon 0.5 hours. To this solution, EDCI $\cdot \mathrm{HCl}(0.760 \mathrm{~g}$, $3.97 \mathrm{mmol}, 1$. equivalent) was then added and the reaction mixture left stirring at $0{ }^{\circ} \mathrm{C}$ for a further 0.5 hours. The mixture was allowed to warm to RT and stirred for an additional 24 hours. All insoluble residues were filtered and the filtrate concentrated in vacuo and dissolved in $\mathrm{CH}_{2} \mathrm{Cl}_{2}(100 \mathrm{ml})$ which was washed with $1 \mathrm{M} \mathrm{HCl}(2 \times 100 \mathrm{ml}), \mathrm{NaHCO}_{3}$ (sat. aq., 100 $\mathrm{ml}$ ), water $(100 \mathrm{ml})$ and $\mathrm{NaCl}$ (sat. aq., $100 \mathrm{ml})$. The organic layer was dried over $\mathrm{MgSO}_{4}$, filtered and concentrated in vacuo to afford $\mathbf{6 a}(\boldsymbol{S})$ as a pale yellow oil. Yield: $1.3792 \mathrm{~g}, 85 \%$; $\operatorname{HRMS}(\mathrm{m} / \mathrm{z})\left(\mathrm{ES}^{+}\right)$Calculated for $\left[\mathrm{C}_{26} \mathrm{H}_{22} \mathrm{~N}_{2} \mathrm{O}_{3} \mathrm{Na}\right]^{+} \mathrm{m} / z=433.1528[\mathrm{M}-\mathrm{Na}]^{+}$. Found $m / \mathrm{z}=$ 433.1354. ${ }^{1} \mathrm{H}$ NMR (400 MHz, $\left.\mathrm{CDCl}_{3}\right) \delta 8.50(\mathrm{~d}, J=8.6 \mathrm{~Hz}, 1 \mathrm{H}$, aryl-CH), $8.42(\mathrm{~d}, J=7.8$ $\mathrm{Hz}, 1 \mathrm{H}$, aryl-CH), $8.26-8.14(\mathrm{~m}, 2 \mathrm{H}$, aryl-CH), 7.98 (t, $J=7.8 \mathrm{~Hz}, 1 \mathrm{H}$, aryl-CH), 7.87 (d, $J$ $=7.9 \mathrm{~Hz}, 1 \mathrm{H}$, aryl-CH), $7.81(\mathrm{~d}, J=8.6 \mathrm{~Hz}, 1 \mathrm{H}$ aryl-CH), $7.62(\mathrm{~d}, J=7.1 \mathrm{~Hz}, 1 \mathrm{H}$, aryl-CH), $7.57-7.32\left(\mathrm{~m}, 8 \mathrm{H}\right.$, aryl-CH), $6.29-6.02(\mathrm{~m}, 1 \mathrm{H}$, aliphatic $\mathrm{CH}), 5.40\left(\mathrm{~s}, 2 \mathrm{H}, \mathrm{CH}_{2}\right), 1.80(\mathrm{~d}, J$ $\left.=6.8 \mathrm{~Hz}, 3 \mathrm{H}, \mathrm{CH}_{3}\right) .{ }^{13} \mathrm{C} \mathrm{NMR}\left(101 \mathrm{MHz}, \mathrm{CDCl}_{3}\right) \delta 164.1,162.3,150.1,146.5,138.5,138.4$, $135.4,133.9,131.0,128.8,128.6,128.4,128.2,128.1,127.3,126.4,125.7,125.5,125.3$, 123.3, 122.6, 67.4, 44.9, 21.4. IR $v_{\max }\left(\mathrm{cm}^{-1}\right): 3385,3301,3049,2979,2875,2319,1725$, $1671,1598,1588,1571,1511,1446,1397,1376,1306,1285,1232,1163,1132$, 1078, 998, $959,908,862,843,800,778,750,733,696$. 
(R)-6-((1-(naphthalen-1-yl)ethyl)carbamoyl)pyridine-2-(carboxylic acid) - 7(S)

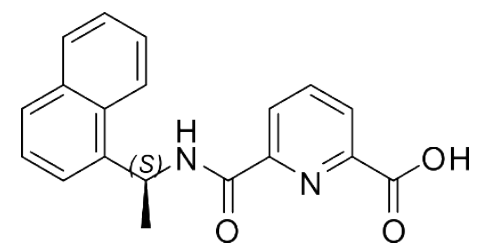

Compound $\mathbf{6 a}(S)(1.34 \mathrm{~g}, 3.36 \mathrm{mmol}, 1$ equiv.) was dissolved in $\mathrm{CH}_{3} \mathrm{OH}(60 \mathrm{~mL})$ treated with $10 \mathrm{wt} \% \mathrm{Pd} / \mathrm{C}(0.054 \mathrm{~g}, 0.05$ mmol, 0.15 equivalent). The reaction mixture was placed in a Parr hydrogen shaker under $\mathrm{H}_{2}$ (3 atm.) and shaken for 24 hours. After the reaction had gone to completion, the mixture was filtered through Celite ${ }^{\circledR}$ and the filtrate concentrated in vacuo to afford $7(S)$ as off white crystals. Yield: $0.95 \mathrm{~g}, 88 \%$; m.p. $102-104{ }^{\circ} \mathrm{C}$; HRMS $(m / z)\left(\mathrm{ES}^{-}\right)$Calculated for $\left[\mathrm{C}_{19} \mathrm{H}_{15} \mathrm{~N}_{2} \mathrm{O}_{3}\right]^{-} \quad m / z=319.1088[\mathrm{M}-\mathrm{H}]^{-}$. Found $m / z=319.1085 ;{ }^{1} \mathrm{H}$ NMR $\left(400 \mathrm{MHz}, \mathrm{CDCl}_{3}\right) \delta 8.44(\mathrm{~d}, J=7.8 \mathrm{~Hz}, 1 \mathrm{H}$, aryl-CH), 8.27 $(\mathrm{d}, J=7.7 \mathrm{~Hz}, 1 \mathrm{H}$, aryl-CH), $8.15(\mathrm{~d}, J=8.2 \mathrm{~Hz}, 1 \mathrm{H}$, aryl-CH), 8.09 (d, $J=8.4 \mathrm{~Hz}, 1 \mathrm{H}$, aryl$\mathrm{CH}), 8.03$ (t, $J=7.8 \mathrm{~Hz}, 1 \mathrm{H}$, aryl-CH), 7.82 (d, $J=8.2 \mathrm{~Hz}, 1 \mathrm{H}$ aryl-CH), 7.75 (d, $J=8.1 \mathrm{~Hz}$, 1H, naphthyl-CH), $7.57-7.43(\mathrm{~m}, 3 \mathrm{H}$, aryl-CH), $7.43-7.37$ (m, 1H, aryl-CH), $6.16-5.88$ (m, 1H, aliphatic $\left.\mathrm{CH}_{2}\right), 1.73\left(\mathrm{~d}, J=6.8 \mathrm{~Hz}, 3 \mathrm{H}, \mathrm{CH}_{3}\right) .{ }^{13} \mathrm{C} \mathrm{NMR}\left(101 \mathrm{MHz}, \mathrm{CDCl}_{3}\right) \delta 163.8$, $162.0,149.2$, 145.0, 139.5, 137.7, 133.8, 131.0, 128.8, 128.4, 126.7, 126.6, 125.8, 125.2, 123.1, 122.8, 50.8, 45.1, 20.8. IR $v_{\max }\left(\mathrm{cm}^{-1}\right): 3259,2981,1735,1647,1598,1523,1453$, $1346,1285,1238,1173,1141,1077,1000,920,846,800,777,745,719$.

tButyl (3-aminopropyl)carbamate - 8

To a stirred solution of 1,3-diaminopropane (6 mL, $71.88 \mathrm{mmol}, 1$
equiv. $)$ in $\mathrm{CHCl}_{3}(50 \mathrm{~mL})$ at $0{ }^{\circ} \mathrm{C}$, a solution di-tert-butyldicarbonate (1.57 g, 7.19 mmol, 1 equiv.) in $\mathrm{CHCl}_{3}(20 \mathrm{~mL})$ was added dropwise and stirred at $\mathrm{RT}$ for 24 hours. The reaction mixture was subsequently washed with $\mathrm{NaCl}$ (sat. aq., $3 \times 100 \mathrm{ml}$ ) and water $(1 \times 100 \mathrm{ml})$, dried over $\mathrm{MgSO}_{4}$, filtered and concentrated in vacuo to afford $\mathbf{8}$ as a colourless oil. Yield: $1.05 \mathrm{~g}, 84 \%$; HRMS (m/z) $(\mathrm{ES}-)$ Calculated for $\left[\mathrm{C}_{8} \mathrm{H}_{17} \mathrm{~N}_{2} \mathrm{O}_{2}\right]^{-} \mathrm{m} / \mathrm{z}=$ $173.1290[\mathrm{M}-\mathrm{H}]^{-}$. Found $m / z=173.1283 ;{ }^{1} \mathrm{H}$ NMR (400 MHz, $\left.\mathrm{CDCl}_{3}\right) \delta 3.21\left(\mathrm{~m}, 2 \mathrm{H}, \mathrm{CH}_{2}\right)$, 2.76 (t, $J=7 \mathrm{~Hz}, 2 \mathrm{H}, \mathrm{CH}_{2}$ ), 1.61 (t, $J=7 \mathrm{~Hz}, 2 \mathrm{H}, \mathrm{CH}_{2}$ ), 1.44 (s, 9H, $\mathrm{CH}_{3}$ ), 1.37 (br. S., 2H, $\left.\mathrm{NH}_{2}\right) .{ }^{13} \mathrm{C} \mathrm{NMR}\left(101 \mathrm{MHz}, \mathrm{CDCl}_{3}\right) \delta 156.1,78.9,39.5,38.2,33.3,28.3$.

(R)-(3-(6-((1-(naphthalen-1-yl) ethyl)carbamoyl)pyridine-2-amido)propyl)carbamate349 - 9(S)<smiles>CC(NC(=O)c1cccc(C(=O)NCCCNC(=O)OC(C)(C)C)n1)c1cccc2ccccc12</smiles>
Compound $7(S)(0.843 \mathrm{~g}, 2.63 \mathrm{mmol}, 1$ equiv.) was dissolved in anhydrous THF $(50 \mathrm{~mL})$ at $0{ }^{\circ} \mathrm{C}$ and HOBt (0.356 g, $2.63 \mathrm{mmol}, 1$ equiv.), $\mathrm{NEt}_{3}(0.37 \mathrm{~mL}, 2.63 \mathrm{mmol}, 1$ equiv. $)$ and $\mathbf{8}$ (0.4615 g, $2.63 \mathrm{mmol}, 1$ equiv.) were added to the solution. $\mathrm{EDCI} \cdot \mathrm{HCl}(0.50 \mathrm{~g}, 2.63 \mathrm{mmol}, 1$ equiv.) was then added and the mixture allowed to warm to RT after 0.5 hours. After 24 
hours stirring at RT all insoluble materials were filtered, the filtrate concentrated in vacuo and the recovered residue dissolved in $\mathrm{CH}_{2} \mathrm{Cl}_{2}$. The organic phase was washed with $1 \mathrm{M} \mathrm{HCl}$ (2 x $100 \mathrm{~mL}$ ), $\mathrm{NaHCO}_{3}$ (sat. aq., $100 \mathrm{~mL}$ ), $\mathrm{H}_{2} \mathrm{O}(100 \mathrm{~mL}$ ) and $\mathrm{NaCl}$ (sat. aq., $100 \mathrm{~mL}$ ). The organic phase was dried over $\mathrm{MgSO}_{4}$, filtered and concentrated in vacuo to afford $\mathbf{9}(\boldsymbol{S})$ as a pale yellow solid. Yield: 0.99g, 79\%; m.p. $80-83{ }^{\circ} \mathrm{C}$; HRMS $(\mathrm{m} / \mathrm{z})\left(\mathrm{ES}^{+}\right)$Calculated for $\left[\mathrm{C}_{27} \mathrm{H}_{32} \mathrm{~N}_{4} \mathrm{O}_{4} \mathrm{Na}\right]^{+} m / z=499.2321[\mathrm{M}+\mathrm{Na}]^{+}$. Found $m / z=499.2328 .{ }^{1} \mathrm{H}$ NMR $(400 \mathrm{MHz}$, $\left.\mathrm{CDCl}_{3}\right) \delta 8.69(\mathrm{~s}, 1 \mathrm{H}), 8.63(\mathrm{~s}, 1 \mathrm{H}), 8.35(\mathrm{~d}, J=7.7 \mathrm{~Hz}, 1 \mathrm{H}), 8.27(\mathrm{~d}, J=7.8 \mathrm{~Hz}, 1 \mathrm{H}), 8.18$ (d, $J=8.3 \mathrm{~Hz}, 1 \mathrm{H}), 7.97$ (t, $J=7.8 \mathrm{~Hz}, 1 \mathrm{H}), 7.83$ (d, $J=7.9 \mathrm{~Hz}, 1 \mathrm{H}), 7.73$ (d, $J=8.2 \mathrm{~Hz}$, 1H), $7.62(\mathrm{~d}, J=7.1 \mathrm{~Hz}, 1 \mathrm{H}), 7.56-7.42(\mathrm{~m}, 2 \mathrm{H}), 7.38(\mathrm{~d}, J=8.0 \mathrm{~Hz}, 1 \mathrm{H}), 6.22-6.01$ (m, $1 \mathrm{H}$, aliphatic $\mathrm{CH}), 4.84(\mathrm{~s}, 1 \mathrm{H}$, amide- $\mathrm{NH}), 3.53-3.36\left(\mathrm{~m}, 2 \mathrm{H}, \mathrm{CH}_{2}\right), 3.19-3.08(\mathrm{~m}, 2 \mathrm{H}$, $\left.\mathrm{CH}_{2}\right), 1.76\left(\mathrm{~d}, J=6.9 \mathrm{~Hz}, 3 \mathrm{H}, \mathrm{CH}_{3}\right), 1.66-1.53\left(\mathrm{~m}, 2 \mathrm{H}, \mathrm{CH}_{2}\right), 1.40\left(\mathrm{~s}, 9 \mathrm{H}, \mathrm{CH}_{3}\right) .{ }^{13} \mathrm{C} \mathrm{NMR}$ $\left(101 \mathrm{MHz}, \mathrm{CDCl}_{3}\right) \delta 163.7,162.7,148.9,148.8,138.7,133.9,130.9,128.8,128.0,126.4$, $125.6,125.2,124.9,124.7,123.3,122.9,79.5,67.9,45.3,36.4,34.8,30.9,30.5,28.4,28.4$, 25.6, 21.2. IR $v_{\max }\left(\mathrm{cm}^{-1}\right): 3305,2978,2933,2324,1655,1599,1513,1443,1391,1365$, 1311, 1274, 1243, 1164, 1143, 1072, 999, 955, 935, 918, 845, 800, 777, 727, 675, 663.

(R)-6-((1-(naphthalen-1-yl)ethyl)carbamoyl)-2-((3-aminopropyl)carbamoyl)- pyridine - 9a(S)<smiles>C[C@H](NC(=O)c1cccc(C(=O)NCCCN)n1)c1cccc2ccccc12</smiles>

To a solution of $9(\boldsymbol{S})$ in anhydrous $\mathrm{CH}_{2} \mathrm{Cl}_{2}(0.78,2.08$ mmol, 1 equiv.) TFA was added $(5 \mathrm{~mL}, 65.3 \mathrm{mmol})$ and the reaction stirred under an argon atmosphere. The reaction was monitored until completion then diluted with $\mathrm{CH}_{2} \mathrm{Cl}_{2}(50 \mathrm{~mL})$ and basified to $\mathrm{pH} 10$ with $1 \mathrm{M} \mathrm{NaOH}$. The organic phase was isolated and washed with $\mathrm{H}_{2} \mathrm{O}(100 \mathrm{~mL})$ and $\mathrm{NaCl}$ (sat. aq., $100 \mathrm{~mL}$ ) before being dried over $\mathrm{MgSO}_{4}$, filtered and concentrated in vacuo to afford $9 \mathrm{a}(\boldsymbol{S})$ as an off-white solid. Yield: $0.46 \mathrm{~g}$, $75 \%$; m.p. $85-88{ }^{\circ} \mathrm{C}$; HRMS $(m / z)\left(E S^{+}\right)$Calculated for $\left[\mathrm{C}_{22} \mathrm{H}_{25} \mathrm{~N}_{4} \mathrm{O}_{2} \mathrm{Na}\right]^{+} m / z=377.1732$ $[\mathrm{M}+\mathrm{H}]^{+}$. Found $m / z=377.1978 ;{ }^{1} \mathrm{H}$ NMR $\left(400 \mathrm{MHz}, \mathrm{CDCl}_{3}\right) \delta 9.35$ (br. s, $\left.1 \mathrm{H}\right), 8.37(\mathrm{~d}, J=$ $7.1 \mathrm{~Hz}, 1 \mathrm{H}), 8.28$ (d, $J=7.7 \mathrm{~Hz}, 1 \mathrm{H}), 8.24(\mathrm{~d}, J=8.2 \mathrm{~Hz}, 1 \mathrm{H}), 8.13$ (d, $J=7.9 \mathrm{~Hz}, 1 \mathrm{H}), 8.00$ (t, $J$ $=7.8 \mathrm{~Hz}, 1 \mathrm{H}), 7.88(\mathrm{~d}, J=7.2 \mathrm{~Hz}, 1 \mathrm{H}), 7.84(\mathrm{~d}, J=8.3 \mathrm{~Hz}, 1 \mathrm{H}), 7.63(\mathrm{~d}, J=7.1 \mathrm{~Hz}, 1 \mathrm{H}), 7.56-$ $7.45(\mathrm{~m}, 3 \mathrm{H}), 6.21-6.06(\mathrm{~m}, 1 \mathrm{H}), 3.47(\mathrm{t}, J=13.3 \mathrm{~Hz}, 2 \mathrm{H}), 2.77-2.62(\mathrm{~m}, 2 \mathrm{H}), 1.81(\mathrm{~d}, J=6.7$ $\mathrm{Hz}, 3 \mathrm{H}), 1.62-1.47(\mathrm{~m}, 2 \mathrm{H}), 1.10(\mathrm{~s}, 2 \mathrm{H}) .{ }^{13} \mathrm{C} \mathrm{NMR}\left(101 \mathrm{MHz}, \mathrm{CDCl}_{3}\right) \delta 163.3,162.6,149.0$, $148.3,138.8,137.9,133.9,131.3,128.7,128.7,126.9,126.1,125.0,124.6,124.5,123.5,122.7$, 44.8, 41.6, 39.9, 30.0, 20.2. IR $v_{\max }\left(\mathrm{cm}^{-1}\right): 3283,2981,2932,1648,1598,1522,1442,1376$, 1340, 1311, 1239, 1173, 1119, 1074, 999, 966, 910, 845, 800, 777, 746, 719, 677. 
(R)-6-((1-(naphthalen-1-yl)ethyl)carbamoyl)-2-((3-methacrylamidopropyl)-carbamoyl)pyridine $-2(S)$<smiles>C=C(C)C(=O)NCCCNC(=O)c1cccc(C(=O)NC(C)c2cccc3ccccc23)n1</smiles>
To a solution of $9 \mathrm{a}(\boldsymbol{S})(0.165 \mathrm{~g}, 0.44 \mathrm{mmol}, 1$ equiv.) in $\mathrm{CH}_{2} \mathrm{CL}_{2}(20 \mathrm{~mL})$ at $0{ }^{\circ} \mathrm{C}$ methacrylic anhydride $(0.27 \mathrm{~mL}, 1.76 \mathrm{mmol}, 4$ equiv.) was added and the reaction stirred at RT for 24 hours. The reaction mixture was subsequently diluted with $\mathrm{CH}_{2} \mathrm{Cl}_{2}(50 \mathrm{~mL})$ and washed with $\mathrm{H}_{2} \mathrm{O}$ $(100 \mathrm{~mL})$ and $\mathrm{NaCl}$ (sat. aq., $100 \mathrm{~mL}$ ). The organic phase was dried over $\mathrm{MgSO}_{4}$, filtered and concentrated in vacuo to afford a crude oily liquid which was eluted in silica (RediSep ${ }^{\circledR}, 5 \%$ $\mathrm{CH}_{3} \mathrm{OH}$ in $\mathrm{CH}_{2} \mathrm{Cl}_{2}$ ). Product containing fractions were combined and concentrated in vacuo, the recovered residue dissolved in EtOAc and eluted on silica (RediSep ${ }^{\circ}, 100 \%$ EtOAc). Again, product containing fractions were combined and concentrated in vacuo to afford $\mathbf{2}(\boldsymbol{S})$ as a glassy oil. Yield: $0.095 \mathrm{~g}, 48 \%$; m.p. $90-92{ }^{\circ} \mathrm{C}$; HRMS $(\mathrm{m} / \mathrm{z})\left(\mathrm{ES}^{-}\right)$Calculated for $\left[\mathrm{C}_{26} \mathrm{H}_{27} \mathrm{~N}_{4} \mathrm{O}_{3}\right]^{-} m / z=443.2089[\mathrm{M}-\mathrm{H}]^{-}$. Found $m / z=443.2093 ;{ }^{1} \mathrm{H} \mathrm{NMR}(400 \mathrm{MHz}, \mathrm{CDCl} 3)$ $\delta 9.42(\mathrm{~s}, 1 \mathrm{H}), 9.18-9.12(\mathrm{~m}, 1 \mathrm{H}), 8.35(\mathrm{~d}, J=7.8 \mathrm{~Hz}, 1 \mathrm{H}), 8.28(\mathrm{~d}, J=7.7 \mathrm{~Hz}, 1 \mathrm{H}), 8.24(\mathrm{~d}, J=$ $8.5 \mathrm{~Hz}, 1 \mathrm{H}), 7.98$ (t, $J=7.8 \mathrm{~Hz}, 1 \mathrm{H}), 7.83$ (d, $J=8.0 \mathrm{~Hz}, 1 \mathrm{H}), 7.72$ (d, $J=8.1 \mathrm{~Hz}, 1 \mathrm{H}), 7.64$ (d, $J$ $=7.1 \mathrm{~Hz}, 1 \mathrm{H}), 7.55-7.43(\mathrm{~m}, 2 \mathrm{H}), 7.35(\mathrm{t}, J=7.7 \mathrm{~Hz}, 1 \mathrm{H}), 6.22-6.11(\mathrm{~m}, 2 \mathrm{H}), 5.73(\mathrm{~s}, 1 \mathrm{H})$, $5.33(\mathrm{~s}, 1 \mathrm{H}), 3.55-3.34(\mathrm{~m}, 4 \mathrm{H}), 1.94(\mathrm{~s}, 3 \mathrm{H}), 1.75(\mathrm{~d}, J=6.9 \mathrm{~Hz}, 3 \mathrm{H}), 1.69-1.64(\mathrm{~m}, 2 \mathrm{H}) .{ }^{13} \mathrm{C}$ NMR $\left(101 \mathrm{MHz}, \mathrm{CDCl}_{3}\right) \delta 169.7,163.7,162.8,148.9,139.5,139.3,138.7,133.8,131.0,128.6$, $127.7,126.2$, 125.5, 125.1, 124.8, 124.4, 123.5, 122.9, 120.5, 45.1, 35.4, 34.2, 29.9, 21.2, 18.9, 14.2. IR $v_{\max }\left(\mathrm{cm}^{-1}\right): 3295,2980,1654,1613,1517,1443,1397,1374,1311,1226,1174,1119$, $1088,1073,1000,979,924,845,800,777,744,726,676,663$.

Preparation of complexes under microwave irradiation

Ligand was dissolved in $\mathrm{CH}_{3} \mathrm{OH}(5 \mathrm{~mL})$ and treated with 0.33 equivalents of the appropriate $\mathrm{Ln}$ (III) salt for 30 minutes at $70{ }^{\circ} \mathrm{C}$. The resulting solutions were concentrated in vacuo then re-dissolved into minimal $\mathrm{CH}_{3} \mathrm{OH}$. The concentrated solution was subsequently precipitated in rapidly stirred diethyl ether $(100 \mathrm{ml})$ to give white solids. Precipitates were collected by centrifuging and filtering the recovered solids; products were washed with $\mathrm{Et}_{2} \mathrm{O}$ and dried under high vacuum. 
$\left[\mathbf{E u} .(\mathbf{1}(\boldsymbol{S}, \boldsymbol{S}))_{3}\right]\left(\mathrm{CF}_{3} \mathrm{SO}_{3}\right)_{3}: \quad$ HRMS $\quad(\mathrm{m} / \mathrm{z}) \quad(\mathrm{MALDI})$ Calculated for $[\mathbf{E u . ( 1}$ $\left.(\boldsymbol{S}, \boldsymbol{S})(\boldsymbol{S}, \boldsymbol{S}))_{2}\right]\left(\mathrm{CF}_{3} \mathbf{S O}_{3}\right)_{2} \mathrm{~m} / \mathrm{z}=1677.4359$. Found $=1667.4328$. IR $v_{\max }\left(\mathrm{cm}^{-1}\right): 3328,3067$, 2981, 1598, 1558, 1524, 1380, 1245, 1158, 1245, 1028, 859, 776.

[Eu. $\left.(\mathbf{2}(\boldsymbol{S}))_{3}\right]\left(\mathrm{CF}_{3} \mathbf{S O}_{3}\right)_{3}$ : HRMS $(\mathrm{m} / \mathrm{z})(\mathrm{MALDI})$ Calculated for $\left[\mathbf{E u} .(\mathbf{2}(\boldsymbol{S}))_{2}\right]\left(\mathrm{CF}_{\mathbf{3}} \mathbf{S O}_{3}\right)_{\mathbf{2}} \mathrm{m} / \mathrm{z}=$ 1339.2576. Found $=m / z$ 1339.2639. IR $v_{\max }\left(\mathrm{cm}^{-1}\right): 3296,3096,2982,1632,1596,1560$, $1458,1380,1349,1277,1240,1224,1161,1028,936,862,840,802,779,753,727,660,634$, 572

\section{poly(HEMA-co-EGDMA-co-1 $(S, S))$}

2-hydroxyethyl methacrylate (HEMA, $10 \mathrm{~mL}$ ), ethylene glycol dimethacrylate (EGDMA, 0.1 $\mathrm{mL})$ and $\mathbf{1}(S, S)(1,5$ or $10 \mathrm{mg}, 0$ were stirred at RT till complete dissolution had occurred. AIBN (100 mg) was added and the clear, homogenous solution injected into a non-stick mould and placed in a $90{ }^{\circ} \mathrm{C}$ oven for 6 hours. Then resulting acrylic materials were allowed to cool to RT, removed from the moulds and washed in excess $\mathrm{H}_{2} \mathrm{O}$ to remove initiator sideproducts and unreacted monomer. IR $v_{\max }\left(\mathrm{cm}^{-1}\right): 3412,2946,2884,1702,1453,1384,1244$, $1151,1071,1021,940,896,842,748$.

\section{poly(HEMA-co-EGDMA-co-2(S))}

2-hydroxyethyl methacrylate (HEMA, $10 \mathrm{~mL}$ ), ethylene glycol dimethacrylate (EGDMA, 0.1 $\mathrm{mL})$ and $\mathbf{2}(S)(13.1 \mathrm{mg})$ were stirred at RT till complete dissolution had occurred. AIBN (100 $\mathrm{mg}$ ) was added and the clear, homogenous solution injected into a non-stick mould and placed in a $90{ }^{\circ} \mathrm{C}$ oven for 6 hours. Then resulting acrylic materials were allowed to cool to RT, removed from the moulds and washed in excess $\mathrm{H}_{2} \mathrm{O}$ to remove initiator side-products and unreacted monomer. IR $v_{\max }\left(\mathrm{cm}^{-1}\right): 3412,2933,2873,1719,1453,1388,1239,1151$, 1067, 1023, 943, 897, 851, 748 . 
<smiles>C[C@H](NC(=O)c1cc(Cl)cc(C(=O)N[C@H](C)c2cccc3ccccc23)n1)c1cccc2ccccc12</smiles><smiles>C[C@H](NC(=O)c1cc(NCCCN)cc(C(=O)N[C@H](C)c2cccc3ccccc23)n1)c1cccc2ccccc12</smiles><smiles>C=C(C)C(=O)OC(=O)C(=C)C</smiles>

Scheme S1 Synthesis of symmetrical naphthyl-dpa ligand monomer $\mathbf{1}(\boldsymbol{S}, \boldsymbol{S})$ possessing a pendent methacrylate moiety (i) 1,3-diaminopropane, $\Delta 135^{\circ} \mathrm{C}$, 18 hours; (ii) $\mathrm{NEt}_{3}$ (1.1 equiv.), $\mathrm{CH}_{2} \mathrm{Cl}_{2}$

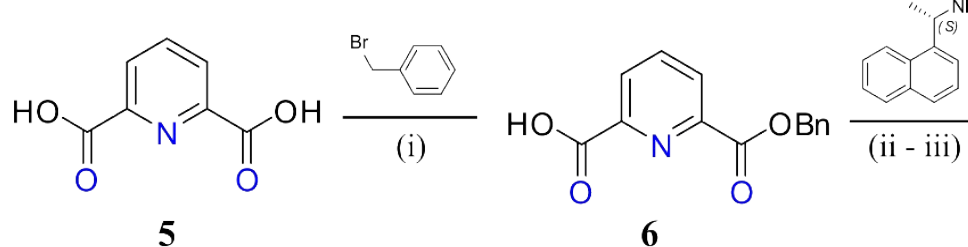<smiles>C[C@H](NC(=O)c1cccc(C(=O)O)n1)c1cccc2ccccc12</smiles><smiles>CC(C)(C)OC(=O)NCCCN</smiles><smiles>CC(C)(C)C</smiles><smiles>C=C(C)C(=O)NCCCNC(=O)c1cccc(C(=O)N[C@H](C)c2cccc3ccccc23)n1</smiles>

$2(S)$ $9(S)$

Schem S2 Synthesis of asymmetrical naphthyl-dpa ligand $2(\boldsymbol{S})$ possessing a methacrylate moiety. (i) $\mathrm{NaHCO}_{3}, \mathrm{DMF}, 60{ }^{\circ} \mathrm{C}$; (ii) $\mathrm{EDCI}, \mathrm{HOBt}, \mathrm{NEt}_{3}$, THF, $0{ }^{\circ} \mathrm{C} \rightarrow \mathrm{RT}$; (iii) $\mathrm{H}_{2}(3 \mathrm{~atm}), 10 \mathrm{wt} \% \mathrm{Pd} / \mathrm{C}(0.15$ equiv.), $\mathrm{CH}_{3} \mathrm{OH}$, RT; (iv) $\mathrm{Boc}_{2} \mathrm{O}, \mathrm{CHCl}_{3}$, RT; (v) $\mathrm{EDCI}, \mathrm{HOBt}, \mathrm{NEt}$, THF, $0^{\circ} \mathrm{C} \rightarrow \mathrm{RT}$; (vi) TFA: $\mathrm{CH}_{2} \mathrm{Cl}_{2}$ $(1: 3 \mathrm{v} / \mathrm{v})$; (vii) methacrylic anhydride, $\mathrm{NEt}_{3}, \mathrm{CH}_{2} \mathrm{Cl}_{2}$. 

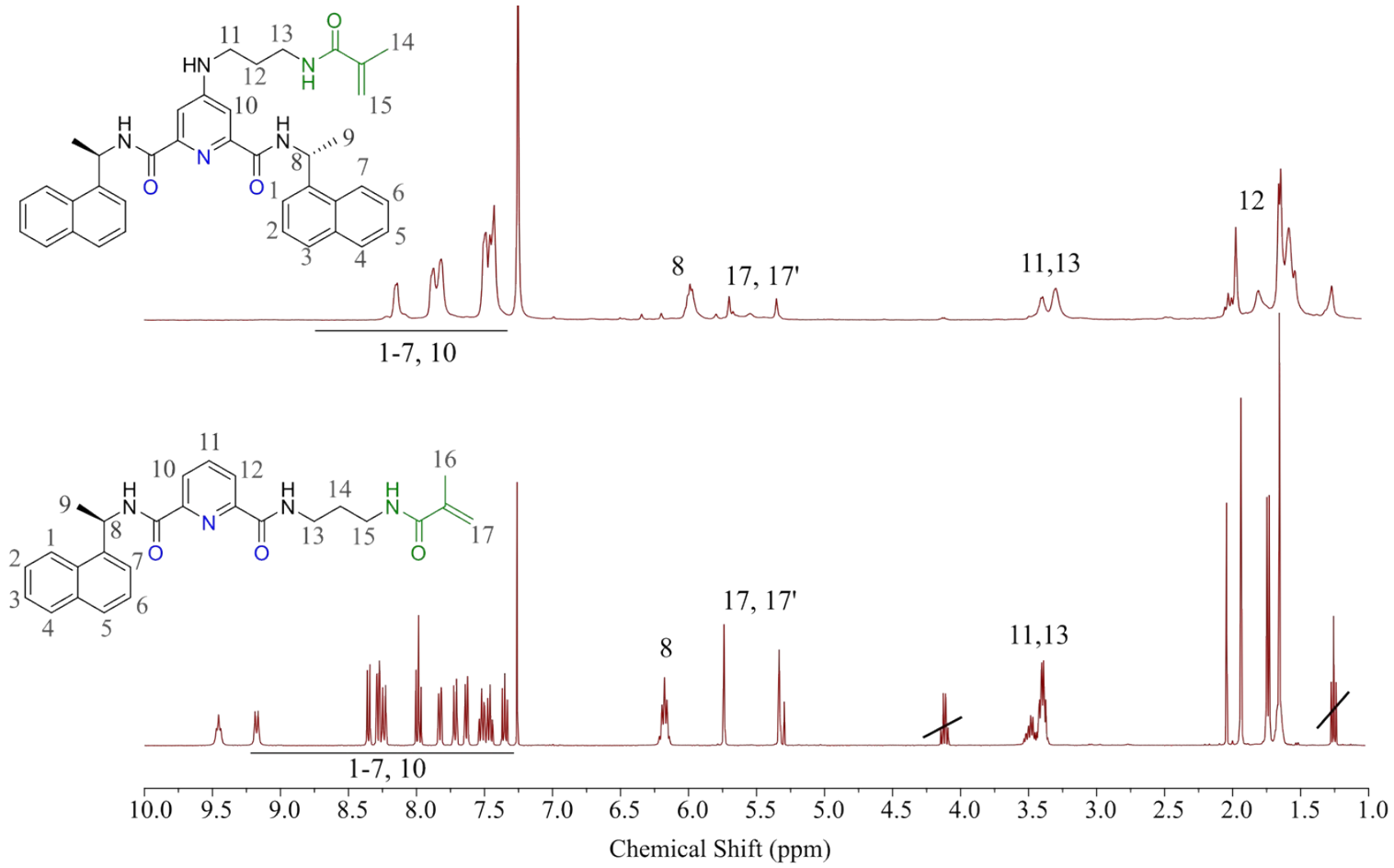

Figure $\mathbf{S 1}{ }^{1} \mathrm{H}$ NMR spectra (400 MHz, $\mathrm{CDCl}_{3}$ ) for ligands a) $\mathbf{1}(\boldsymbol{S}, \boldsymbol{S})$; and b) $\mathbf{2}(\boldsymbol{S})$.

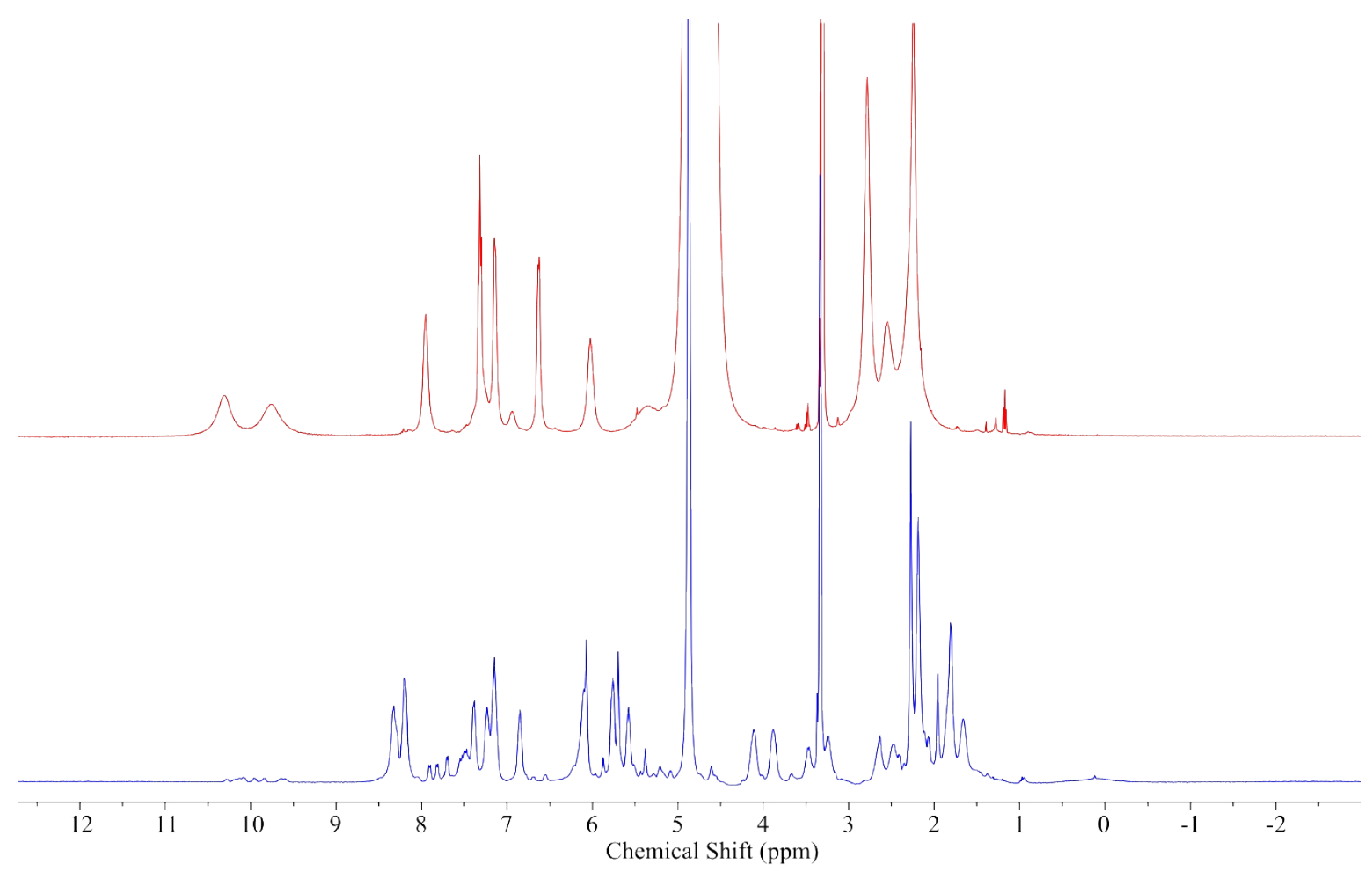

Figure S2 ${ }^{1} \mathrm{H}$ NMR $\left(400 \mathrm{MHz}, \mathrm{CD}_{3} \mathrm{OD}\right)$ for $\left[\mathbf{E u} .(\mathbf{1}(\boldsymbol{S}, \boldsymbol{S}))_{3}\right]\left(\mathbf{C F}_{3} \mathbf{S O}_{3}\right)_{3}$ (red) and $\left[\mathbf{E u} .(2(\boldsymbol{S}))_{2}\right]\left(\mathbf{C F}_{3} \mathbf{S O}_{3}\right)_{3}$ (blue), showing similar LIS consistent with similar geometry and crystal field splitting. Multiple species clearly visible for $\left[\mathbf{E u} .(2(S))_{2}\right]\left(\mathbf{C F}_{3} \mathbf{S O}_{3}\right)_{3}$ (blue) while $\left[\mathbf{E u} .(\mathbf{1}(\mathbf{S}, \mathbf{S}))_{3}\right]\left(\mathbf{C F}_{3} \mathbf{S O}_{3}\right)_{3}$ (red) showed more broadening. 


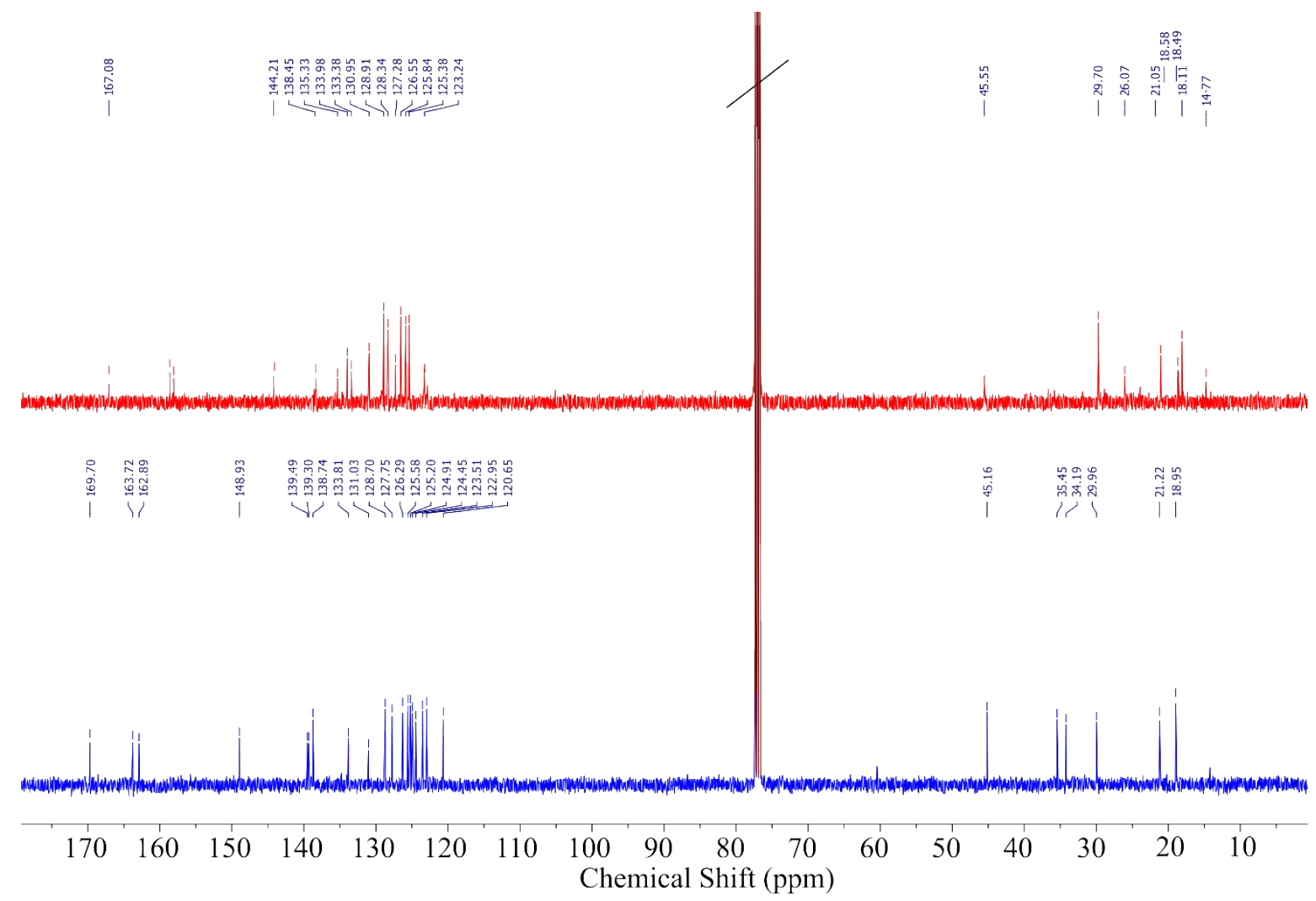

Figure $\mathbf{S 3}{ }^{13} \mathrm{C}$ NMR $\left(600 \mathrm{MHz}, \mathrm{CDCl}_{3}\right)$ for $\mathbf{1}(\boldsymbol{S}, \boldsymbol{S})$ (red) and $\mathbf{2}(\boldsymbol{S})$ (blue).
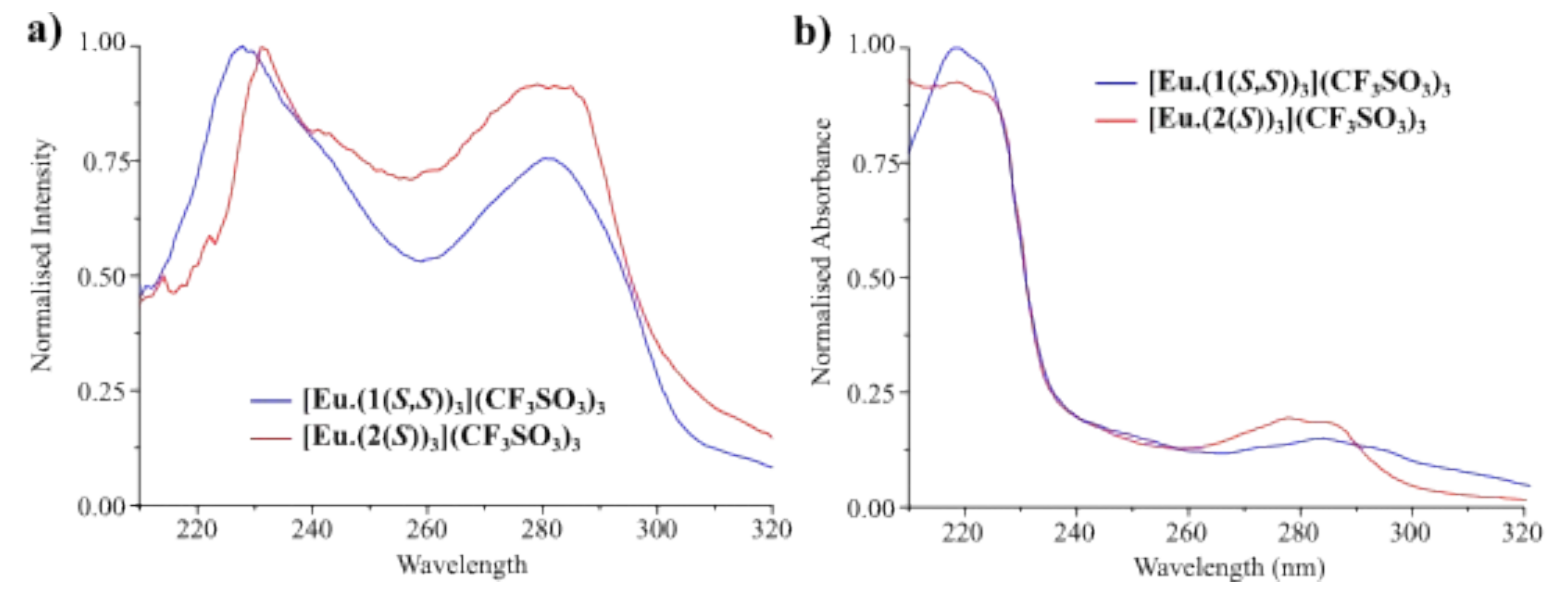

Figure S4 a) Normalised excitation spectra of $\left[\mathbf{E u} .(1(S, S))_{3}\right]\left(\mathrm{CF}_{3} \mathrm{SO}_{3}\right)_{3}$ (blue) and $\left[\mathrm{Eu} .(2(S))_{2}\right]\left(\mathrm{CF}_{3} \mathrm{SO}_{3}\right)_{3}$ (red), showing key structural features of the ligand absorbance bands in $\mathrm{CH}_{3} \mathrm{CN}$; and b) normalised absorption spectra for $\left[\mathbf{E u} .(\mathbf{1}(S, S))_{3}\right]\left(\mathrm{CF}_{3} \mathrm{SO}_{3}\right)_{3}$ and $\left[\mathbf{E u} .(2(S))_{3}\right]\left(\mathrm{CF}_{3} \mathrm{SO}_{3}\right)_{3}$ in $\mathrm{CH}_{3} \mathrm{CN}$. 

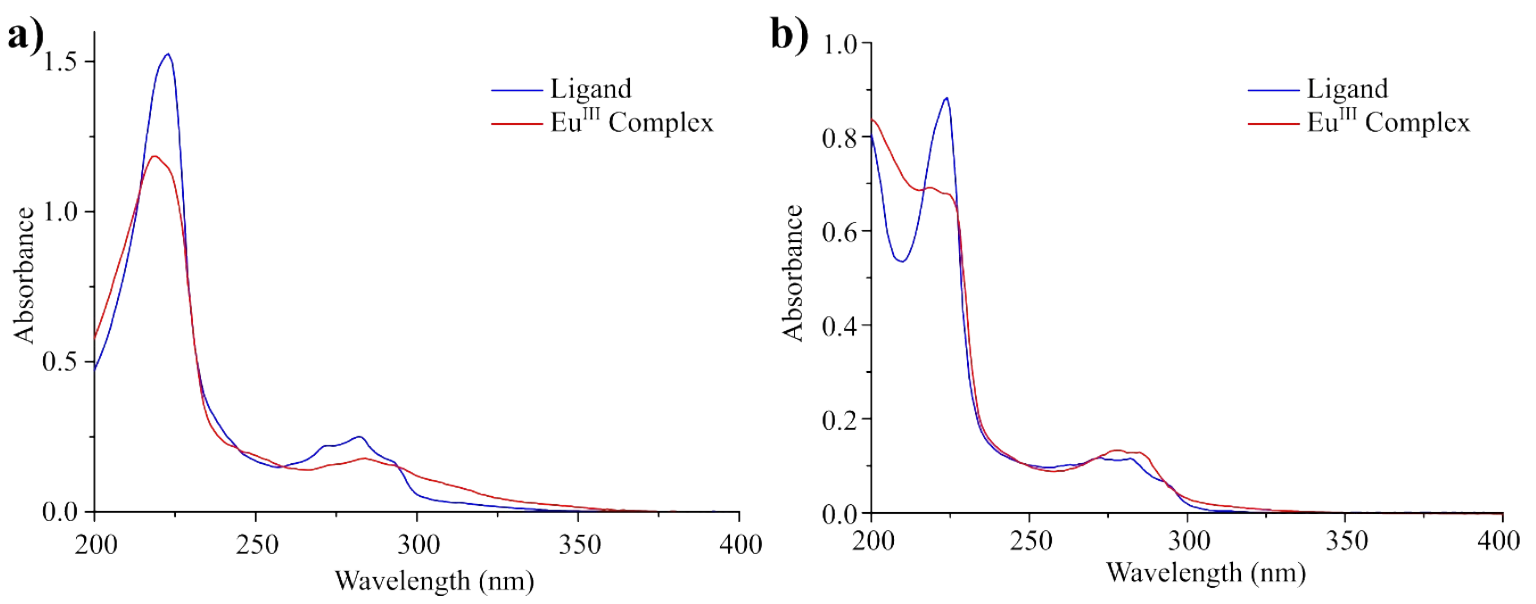

Figure S5 Overlaid UV-visible absorption spectra in $\mathrm{CH}_{3} \mathrm{CN}$ for: a) $\mathbf{1}(\boldsymbol{S}, \boldsymbol{S})$ (blue) and $\left[\mathbf{E u} .(\mathbf{1}(\boldsymbol{S}, \boldsymbol{S}))_{3}\right]^{3+}(\mathrm{red})$; and b) $2(S)$ (blue) and $\left[\mathbf{E u} .(2(S))_{3}\right]^{3+}($ red). Spectra were recorded at effective ligand concentrations of $c=1 \times$ $10^{-5} \mathrm{M}$ at $24^{\circ} \mathrm{C}$.
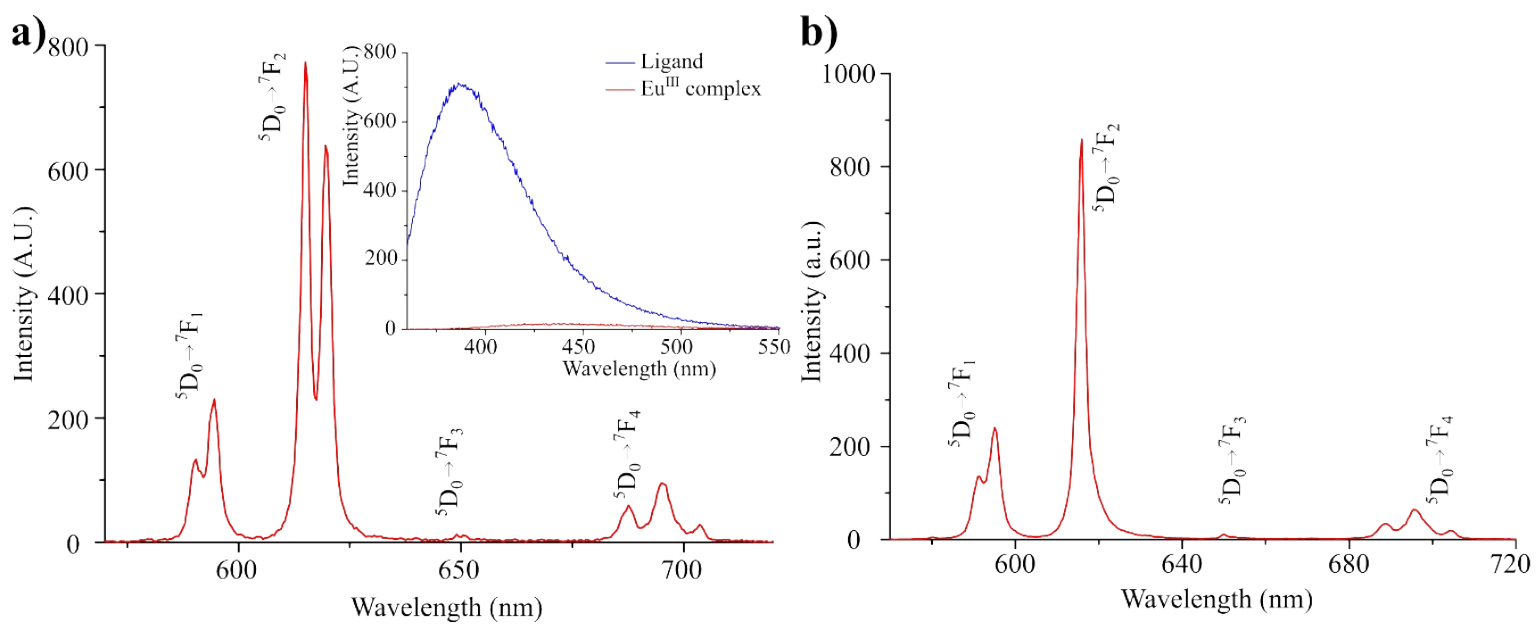

Figure S6 Time-gated emission spectra in $\mathrm{CH}_{3} \mathrm{CN}$ for complexes: a) $\left[\mathbf{E u} .(1(S, S))_{3}\right]^{3+}$ inset: $\mathbf{1}(S, S)$-centred fluorescence emission from $\mathbf{1}(S, S)$ and $\left[\mathbf{E u} .(\mathbf{1}(S, S))_{3}\right]^{3+}$ showing quenching upon coordination; and b) $\left[\mathbf{E u} .(2(S))_{3}\right]^{3+}$. Spectra recorded at effective ligand concentration $c=1 \times 10^{-5} \mathrm{M}$ at $24^{\circ} \mathrm{C}$. 

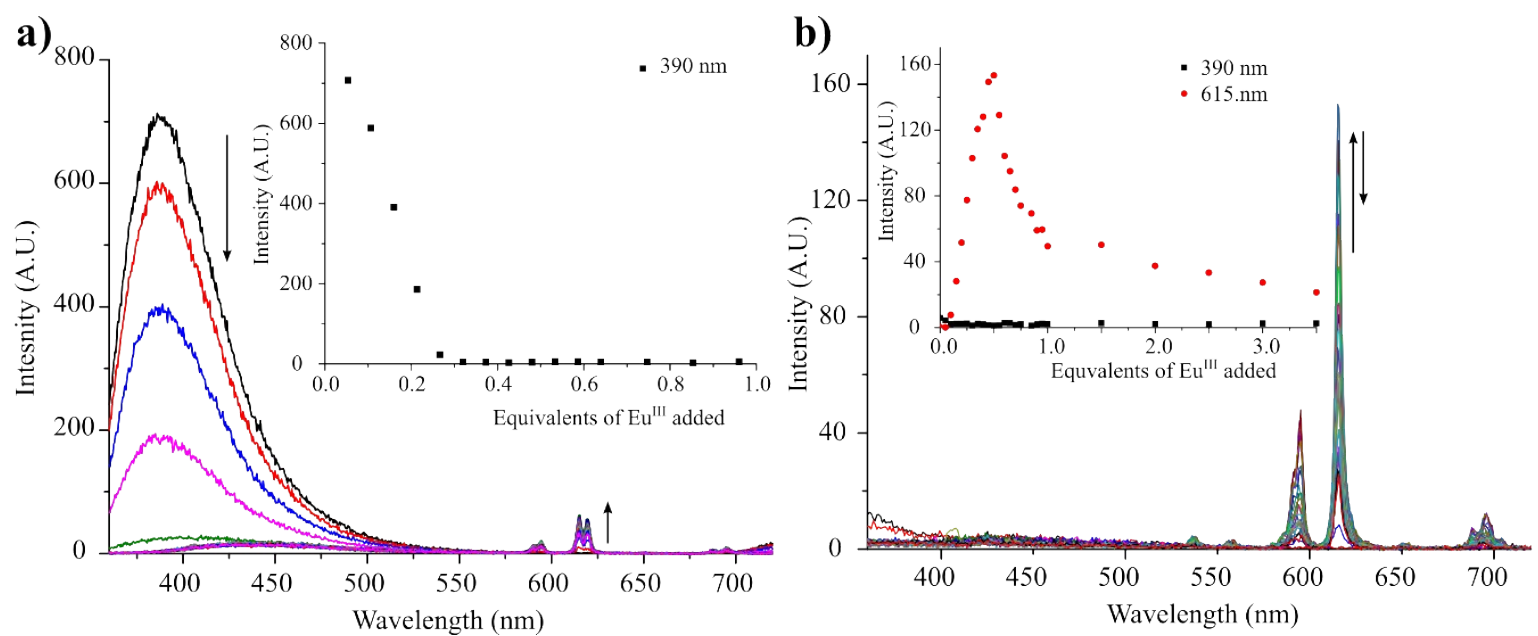

Figure S7 Overlaid fluorescence emission spectra from titrations with $0.00 \rightarrow 4.00$ equivalents of $\mathrm{Eu}\left(\mathrm{CF}_{3} \mathrm{SO}_{3}\right)_{3}$ in $\mathrm{CH}_{3} \mathrm{CN}$ for: a) ligand $\mathbf{1}(\boldsymbol{S}, \boldsymbol{S})$ inset: single wavelength binding isotherms for ligand emission at $\lambda_{\text {em }}=390 \mathrm{~nm}$ as a function of added equivalents of $\mathrm{Eu}(\mathrm{III})$; and b) ligand $2(\boldsymbol{S})$ inset: single wavelength binding isotherms for ligand emission at $\lambda_{\mathrm{em}}=390 \mathrm{~nm}$ and $\mathrm{Eu}(\mathrm{III})$-emission at $\lambda_{\mathrm{abs}}=615 \mathrm{~nm}$ as a function of added equivalents of $\mathrm{Eu}(\mathrm{III})$. Spectra recorded from initial ligand concentrations of $c=1 \times 10^{-5} \mathrm{M}$ at $24{ }^{\circ} \mathrm{C}$.
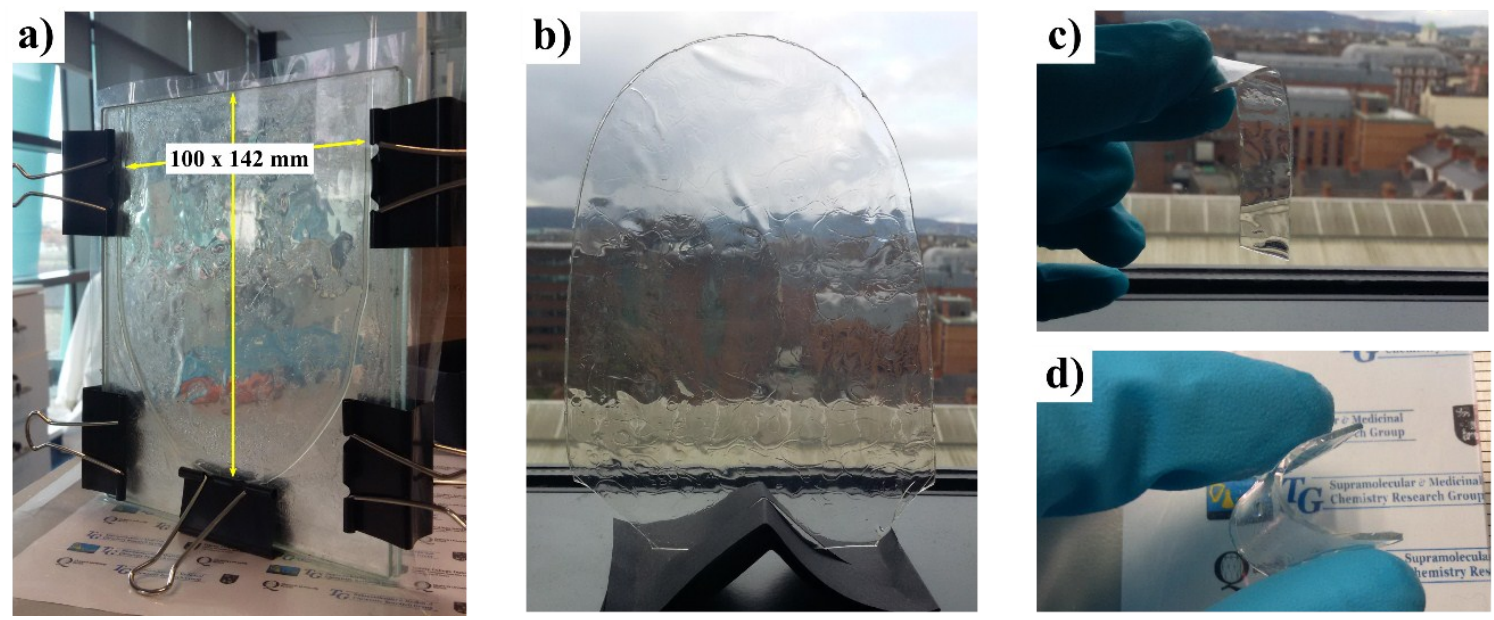

Figure S8 Photographs of: a) cast used to fabricate polymer monoliths made from glass and lined with a non-stick coating; b) polymer monolith of $\mathbf{1}(S, S)$ after 5 hours curing, transparent and hard; and c) and d) cut strips of hard polymer swelled in $\mathrm{H}_{2} \mathrm{O}$ for 2 hours showing soft, flexible materials that remain transparent. 

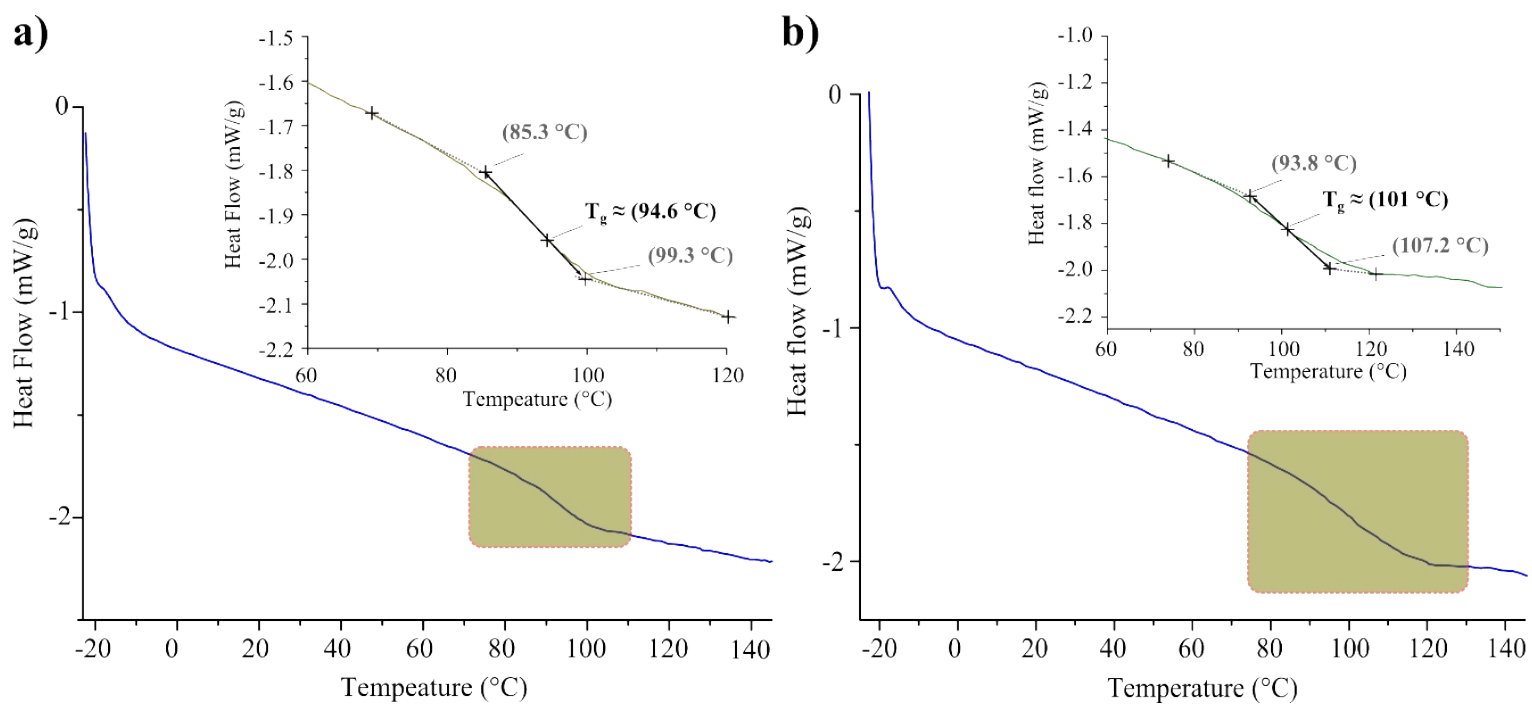

Figure S9 Dynamic scanning calorimetry (DSC) curves recorded from solids samples of: a) p(HEMA-coEGDMA-co-1(S,S)) inset: zoomed region and determination of $\mathrm{T}_{\mathrm{g}}$ from extrapolation methods; and b) $\mathrm{p}$ (HEMA-co-EGDMA-co-2(S)) inset: zoomed region and determination of $\mathrm{T}_{\mathrm{g}}$ from extrapolation methods. Curves showns are second heating cycles and $\mathrm{T}_{\mathrm{g}}$ was determined using therelevant instrument software.
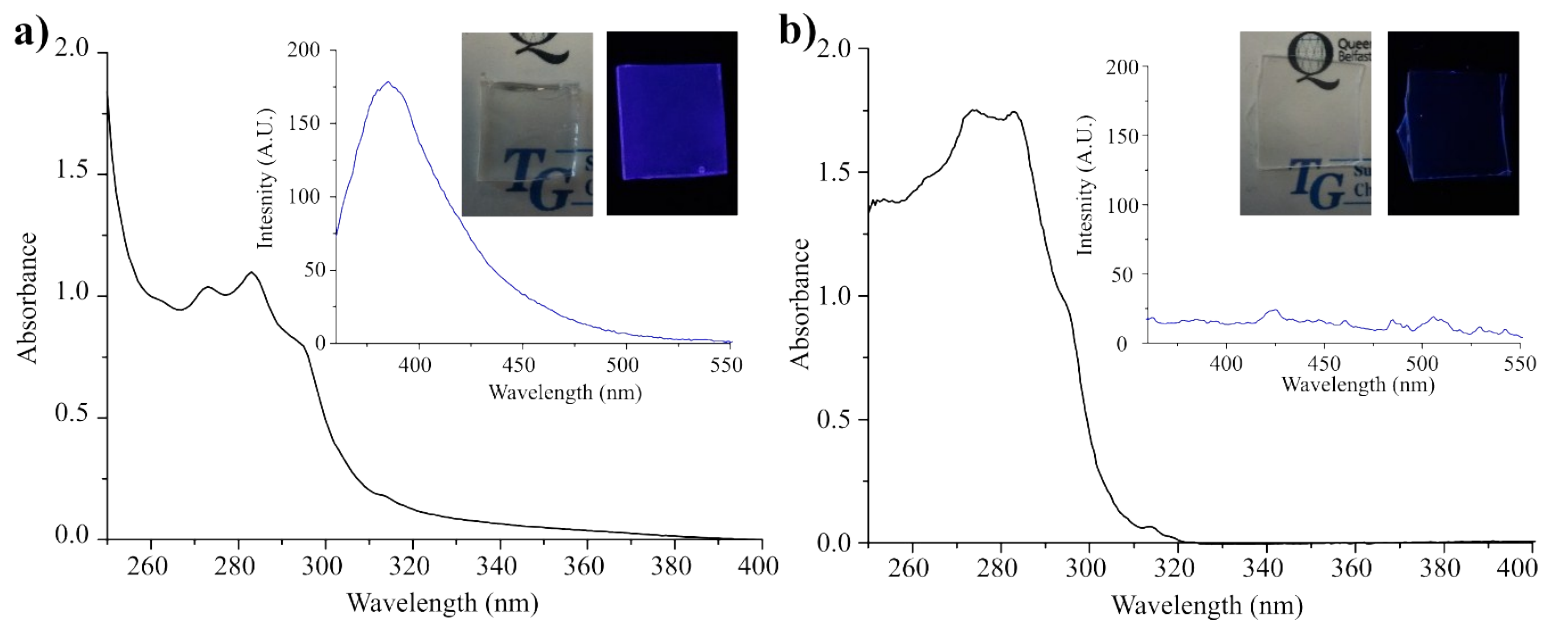

Figure S10 UV-visible absorption and fluorescence emission (inset) spectra of swelled samples of: a) p(HEMA-co-EGDMA-co-1(S,S)); and b) p(HEMA-co-EGDMA-co-2(S)). Materials were equilibrated in $\mathrm{H}_{2} \mathrm{O}$ for 2 hours prior to measurement and fully swelled, the spectra were recorded of gels in supernatant $\mathrm{H}_{2} \mathrm{O}$ at $24^{\circ} \mathrm{C}$. 


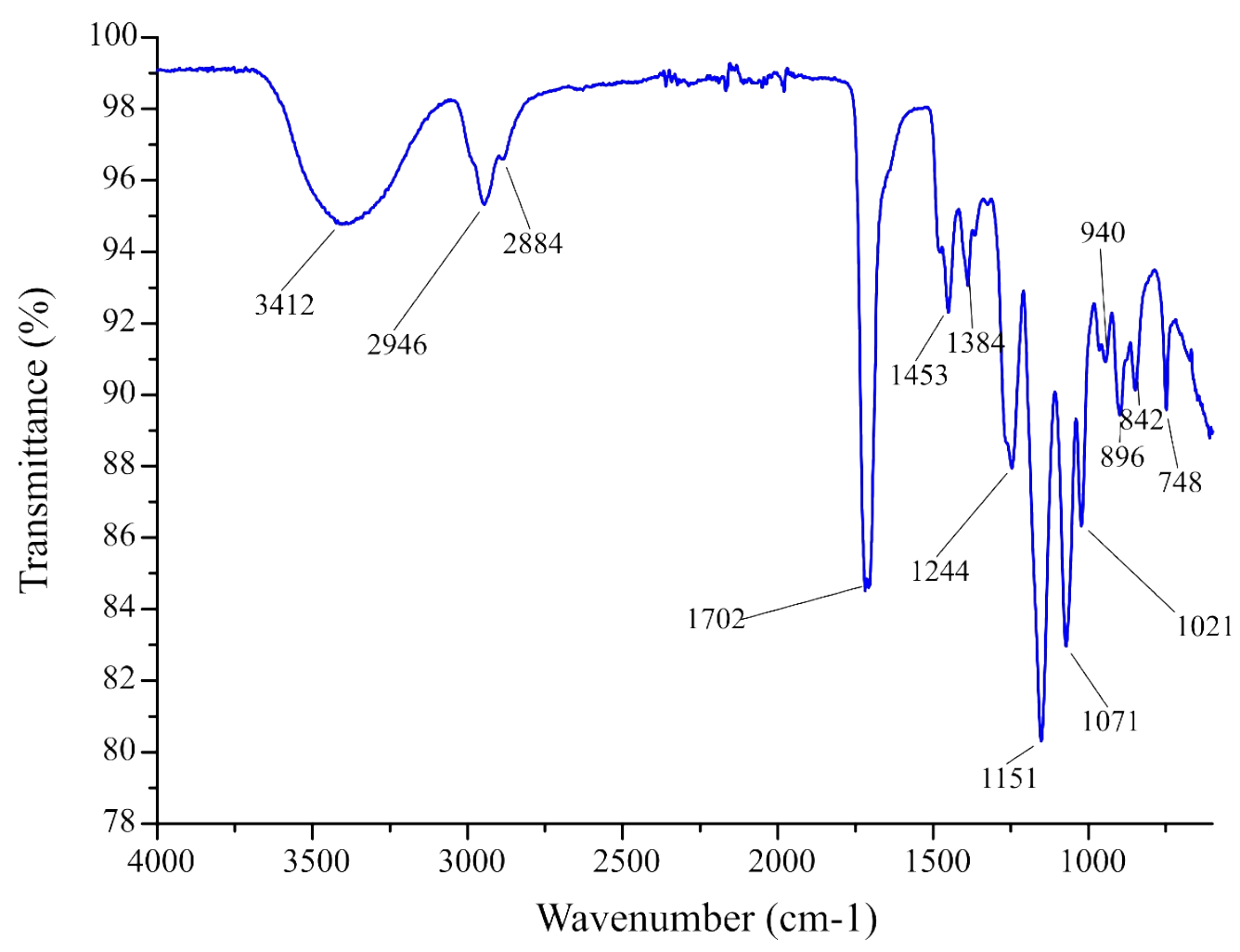

Figure S11 IR spectrum (ATR) of p(HEMA-co-EGDMA-co-1(S,S)).

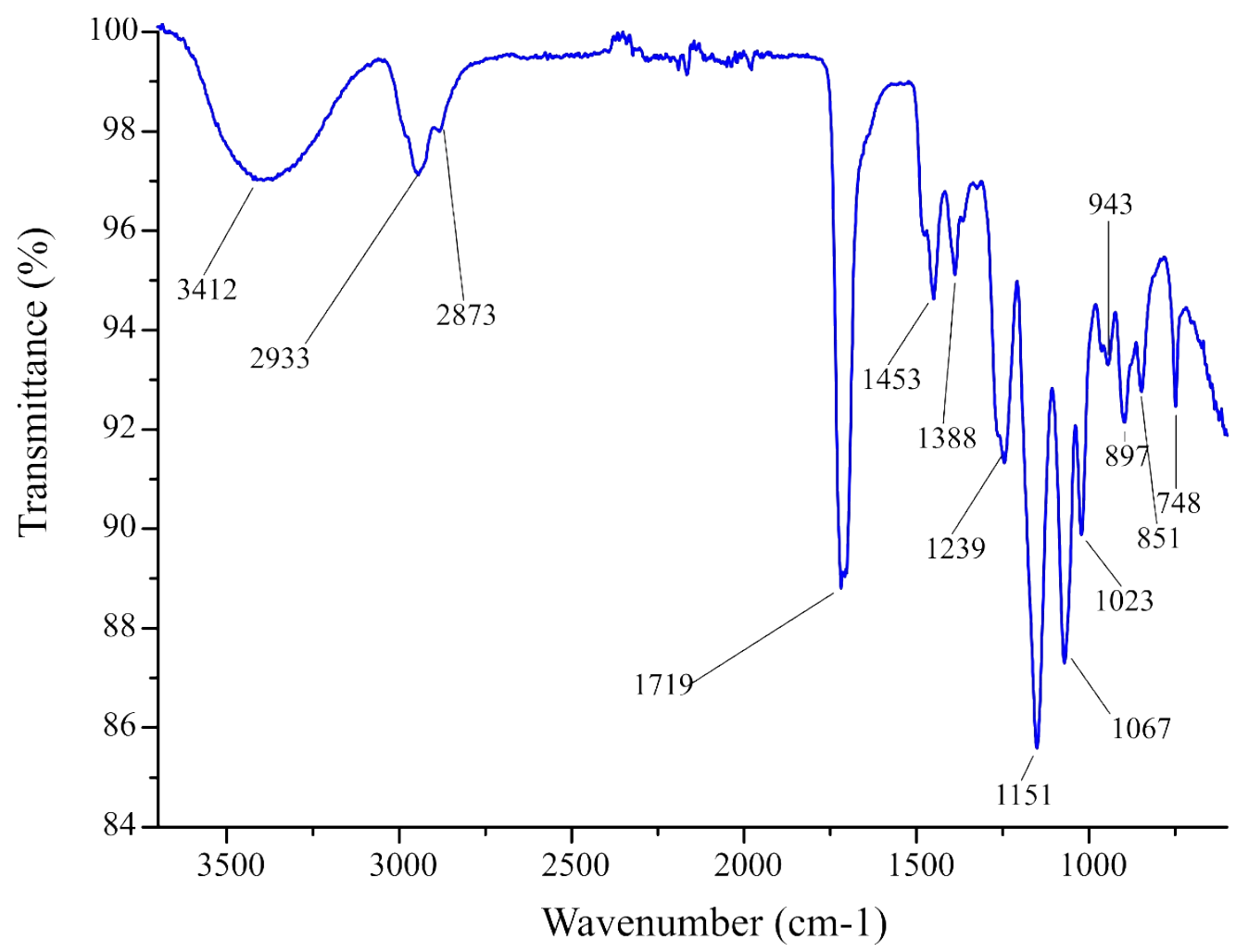

Figure S12 IR spectrum (ATR) of p(HEMA-co-EGDMA-co-2(S)). 
Table S1 Eu(III)-centred luminescence lifetime measurements for $\left[\mathbf{E u} .(\mathbf{1}(\boldsymbol{S}, \boldsymbol{S}))_{3}\right]^{3+}$ and $\left[\mathbf{E u} .(2(S))_{3}\right]^{3+}$ in $\mathrm{H}_{2} \mathrm{O}$, $\mathrm{D}_{2} \mathrm{O}, \mathrm{CH}_{3} \mathrm{CN}$ and $\mathrm{CH}_{3} \mathrm{OH}$ at $\lambda_{\mathrm{em}}=615 \mathrm{~nm}$. Uncertainty was determined as the standard deviation from independent replicates. ${ }^{a}$ Only one emissive species was found in solution.

\begin{tabular}{c|c|cc} 
Complex & Solvent & $\boldsymbol{\tau}_{\mathbf{1}} / \mathbf{m s}$ & $\boldsymbol{\tau}_{\mathbf{2}} / \mathbf{m s}$ \\
\hline$\left[\mathbf{E u .}(\mathbf{1}(\boldsymbol{S}, \boldsymbol{S}))_{\mathbf{n}}\right]^{3+}$ & $\mathrm{CH}_{3} \mathrm{CN}$ & $1.43 \pm 0.02(91 \%)$ & $0.44 \pm 0.01(9 \%)$ \\
& $\mathrm{H}_{2} \mathrm{O}$ & $1.33 \pm 0.01(100 \%)$ & $-^{a}$ \\
& $\mathrm{D}_{2} \mathrm{O}$ & $2.96 \pm 0.02(100 \%)$ & $-^{a}$ \\
& $\mathrm{CH}_{3} \mathrm{OH}$ & $1.29 \pm 0.01$ & $0.48 \pm 0.01$ \\
& $\mathrm{CD}_{3} \mathrm{OD}$ & $2.54 \pm 0.02$ & $0.84 \pm 0.01$ \\
& & & $-{ }^{a}$ \\
& $\mathrm{CH}_{3} \mathrm{CN}$ & $1.43 \pm 0.01(100 \%)$ & $0.30 \pm 0.01(6 \%)$ \\
& $\mathrm{H}_{2} \mathrm{O}$ & $1.43 \pm 0.01(94 \%)$ & $-{ }^{a}$ \\
& $\mathrm{D}_{2} \mathrm{O}$ & $3.20 \pm 0.05(93 \%)$ & $1.77 \pm 0.30(7 \%)$ \\
& $\mathrm{CH}_{3} \mathrm{OH}$ & $0.52 \pm 0.01(100 \%)$ & $\left.-_{\mathbf{n}}\right]^{3+}$
\end{tabular}

Table S2 Number of water molecules bound to $\mathrm{Eu}(\mathrm{III})$ in $\left[\mathbf{E u} .(\mathbf{1}(\boldsymbol{S}, \boldsymbol{S}))_{3}\right]^{3+}$ and $\left[\mathbf{E u} .(\mathbf{2}(\boldsymbol{S}))_{3}\right]^{3+}$ as estimated from $q$-value models of lifetime values in $\mathrm{H}_{2} \mathrm{O}$ and $\mathrm{D}_{2} \mathrm{O}$ and $\mathrm{CH}_{3} \mathrm{OH}$ and $\mathrm{CD}_{3} \mathrm{OD}$ (Table S1) from Horrocks and Parker. The associated error with each $q$-value is \pm 0.5 . ${ }^{a}$ Only one lifetime was identified in solution.

\begin{tabular}{c|c|cccc} 
Complex & Solvents & \multicolumn{2}{|c}{-value (Horrock's) } & \multicolumn{2}{c}{$\boldsymbol{q}$-value (Parker) } \\
\hline & & $\boldsymbol{\tau}_{\mathbf{1}}$ & $\boldsymbol{\tau}_{\mathbf{2}}$ & $\boldsymbol{\tau}_{\mathbf{1}}$ & $\boldsymbol{\tau}_{\mathbf{2}}$ \\
{$\left[\mathbf{E u .}(\mathbf{1}(\boldsymbol{S}, \boldsymbol{S}))_{\mathbf{n}}\right]^{3+}$} & $\mathrm{H}_{2} \mathrm{O} / \mathrm{D}_{2} \mathrm{O}$ & 0.2 & $-a$ & -0.2 & $-a$ \\
{$\left[\mathbf{E u} .(\mathbf{2}(\boldsymbol{S}))_{\mathbf{n}}\right]^{3+}$} & $\mathrm{H}_{2} \mathrm{O} / \mathrm{D}_{2} \mathrm{O}$ & 0.2 & 3.1 & -0.1 & 2.7 \\
& & & & & \\
{$\left[\mathbf{E u} .(\mathbf{1}(\boldsymbol{S}, \boldsymbol{S}))_{\mathbf{n}}\right]^{3+}$} & $\mathrm{CD}_{3} \mathrm{OD} / \mathrm{CH}_{3} \mathrm{OH}$ & 0.2 & 3 & -0.3 & 2.8 \\
{$\left[\mathbf{E u} .(\mathbf{(}(\boldsymbol{S}))_{\mathbf{n}}\right]^{3+}$} & $\mathrm{CD}_{3} \mathrm{OD} / \mathrm{CH}_{3} \mathrm{OH}$ & 3.1 & $-a$ & 2.9 & $-a$
\end{tabular}

Table S3 Eu(III)-centred luminescence lifetime measurements for p(HEMA-co-EGDMA-co-1(S,S)) and p(HEMA-co-EGDMA-co-2(S)) polymer gels after fully equilibrating with 0.33 equivalents $\operatorname{Eu}\left(\mathrm{CF}_{3} \mathrm{SO}_{3}\right)_{3}$ at $\lambda_{\mathrm{em}}$ $=615 \mathrm{~nm}$. Uncertainty was determined as the standard deviation from independent replicates. ${ }^{a}$ Only one emissive species was found in solution. ${ }^{b}$ Samples were dehydrated from swelled gels. ${ }^{c}$ Absolute $q$-values could not be determined.

\begin{tabular}{c|cccc} 
Complex & Solvent & $\boldsymbol{\tau}_{\mathbf{1}} / \mathbf{m s}$ & $\boldsymbol{\tau}_{\mathbf{2}} / \mathbf{m s}$ & $\boldsymbol{q}$-value \\
\hline$\left[\mathbf{E u} .(\mathbf{1}(\boldsymbol{S}, \boldsymbol{S}))_{\mathbf{n}}\right]^{3+}$ & $\mathrm{Dry}^{b}$ & $1.31 \pm 0.01(86 \%)$ & $0.56 \pm 0.01(14 \%)$ & $-^{c}$ \\
& $\mathrm{H}_{2} \mathrm{O}$ & $1.32 \pm 0.01(100 \%)$ & $-^{a}$ & 0 \\
& $\mathrm{D}_{2} \mathrm{O}$ & $2.79 \pm 0.01(100 \%)$ & $-^{a}$ & \\
{$\left[\text { Eu. }(\mathbf{2}(\boldsymbol{S}))_{\mathbf{n}}\right]^{3+}$} & $\mathrm{Dry}^{b}$ & $0.40 \pm 0.02(51 \%)$ & $0.91 \pm 0.01(49 \%)$ & $-^{c}$
\end{tabular}


$\mathrm{H}_{2} \mathrm{O} \quad 0.48 \pm 0.03(100 \%)$

3

$\mathrm{D}_{2} \mathrm{O} \quad 2.65 \pm 0.02(100 \%)$ 